\title{
Aktif Doğrudan veya Yapılandırılmış Buluş: Fen Bilimleri Öğretmenlerinin Fen Öğretimi Yönelimlerinin Belirlenmesi
}

\author{
Active direct or guided inquiry: Examining the Science Teaching Orientations of Science \\ Teachers
}

\author{
Eylem YILDIZ FEYZİOĞLU ${ }^{1}$ \\ Burak FEYZİĞLU ${ }^{2}$ \\ Niymet DEMIRCi ${ }^{3}$
}

Başvuru Tarihi: 15.03.2016

Yayına Kabul Tarihi: 20.09.2016

DOI:10.21764/efd.49128

\begin{abstract}
Özet: $\mathrm{Bu}$ araştırmanın amacı, Fen Bilimleri öğretmenlerinin fen öğretimine yönelik yönelimlerini ve cinsiyet, mesleki kıdem ve görev yeri değişkenlerine göre yönelimlerinin nasıl değiş̧tiğini belirlemektir. Tarama modeline uygun olarak yürütülen araştırmaya, Aydın ilinde görev yapan 95 Fen Bilimleri öğretmeni katılmıştır. Öğretmenlerin fen öğretimi yönelimlerini belirlemek amaciyla Schuster ve diğer. (2007)'nin geliştirdiği Fen Öğretimi Eğitsel Yaklaşım Testi (FÖEYT) kullanılmıştır. FÖEYT'nin Türkçeye uyarlaması Güvenç ve Sert (2013) tarafindan yapılmıştır. 16 maddelik testin seçenekleri doğrudan öğretim, aktif doğrudan, yapılandırılmış sorgulayıcı ve yapılandırılmamış buluş olmak üzere dört farklı yönelimi temsil etmektedir. Araştırmanın sonuçları, öğretmenlerin fen öğretimi yönelimleri yapılandırılmış sorgulayıcı olduğunu göstermiştir. Yani öğrenci önceden belirlenmiş bilimsel bir içeriği öğrenmek için öğretmenin rehberliğinde bir olguyu ya da bir fikri keşfetmeye çalışmaktadır. Ayrıca bayan öğretmenler erkek ögretmenlere göre, mesleki kıdemi 11-20 yıl olan öğretmenler, 1-10 yıl mesleki kıdemi olan öğretmenlere göre ve merkezde görev yapan öğretmenler ilçelerde görev yapan öğretmenlere göre daha yapılandırılmış sorgulayıc1 yönelimlere sahiptir. Cinsiyetin öğretmenlerin fen öğretimi uygulamalarını etkileyen bir unsur olduğu ortaya çıkarken, öğretmenlerin mesleki kıdemleri arttıkça daha çok yapılandırılmış sorgulayıcı yönelimini benimsedikleri belirlenmiştir. Ayrıca, öğretmenlerin yönelimlerini görev yaptıkları kurumun koşullarına göre biçimlendirdikleri ve böylece bulundukları fiziksel koşullarla fen öğretimi yönelimleri arasında yaşadıkları çatışmayı çözebildikleri sonucuna ulaşılmıştır.
\end{abstract}

Anahtar Kelimeler: Fen öğretimi yönelimi, aktif doğrudan, yapılandırılmamış buluş, fen öğretmeni, demografik değişkenler
Abstract: The purpose of this research is to identify the science teaching orientations of the science teachers and to determine how their orientations change according to gender, professional seniority and school location. The study was conducted in line with a survey model in which 95 Science teachers working in the province of Aydin participated. The Pedagogy of Science Teaching Test (POSTT) developed by Schuster et al. (2007) was employed to identify the orientations of the science teachers. The Turkish adaptation of the POSTT was created by Güvenç and Sert (2013). The choices on the 16-item test represent four different basic pedagogies of didactic direct, active direct, guided inquiry and open inquiry. The results of the research revealed that the science teaching orientations of the science teachers were consistent with the pedagogy of guided inquiry. Guided inquiry refers to the teaching method of having a student learn a previously determined scientific content through exploration of a phenomenon or concept under the guidance of the teacher. It was found that female teachers more than male teachers, teachers with a seniority of 11-20 years more than teachers of 1-10 years and teachers working in the city center rather than in the sub-districts were more likely to display an orientation toward guided inquiry. While it was revealed that gender was a factor that affected teachers' science teaching practices, it was also ascertained that the more professionally experienced teachers were the most likely to adopt a guided inquiry orientation. Moreover, it was concluded that teachers shaped their orientations to the conditions prevailing in the school at which they worked and were thus able to resolve the conflicts they experienced between physical conditions and their own science teaching orientations.

Keywords: Science teaching orientation, active direct, guided inquiry, science teacher, demographic factors

\footnotetext{
1 Yrd. Doç. Dr., Adnan Menderes Üniversitesi, Eğitim Fakültesi, İlköğretim Bölümü, eylemyildiz@adu.edu.tr

${ }^{2}$ Yrd. Doç. Dr., Adnan Menderes Üniversitesi, Eğitim Fakültesi, Ortaöğretim Fen ve Matematik Alanlar Eğitimi Bölümü, bfeyzioglu@gmail.com

3 Öğretmen, Ali Şefika Göztepe İlkokulu, niymetdemirci@gmail.com
} 


\section{Giriş}

Günümüzde bireylerden çevresel ve toplumsal olaylara karşı duyarlı olmaları, fen ve teknolojiyi günlük yaşamlarıyla ilişkilendirerek bakmaları, fen kavramlarını öğrenerek süreç becerilerini kullanmaları, fene yönelik tutumlar ve değerler geliştirmeleri beklenmektedir (Kavak, Tufan ve Demirelli, 2006). Bunun içinde bireylerin araştırma-sorgulama, eleştirel düşünme, problem çözme ve karar verme becerilerine sahip olmaları gerekir (Amerikan Ulusal Araştırma Konseyi [NRC], 2014). Fen programlarının bahsedilen bu becerilere sahip bireylerin yetişmesine ne düzeyde katkıda bulunduğu ise tartışma konusudur (Kılıç, Haymana ve Bozyılmaz, 2008; Tabak, 2007). Bu nedenle programlarda önemli değişiklikler yapılırken, öğretmenlerin de bu değişime ayak uydurması beklenmektedir (Cheung, 2007; van Driel, Beijaard ve Verloop, 2001). Türkiye'de 2004-2005 öğretim yılında yapılan program değişikliği incelendiğinde, dersin öğrenme öğretme sürecine yönelik yapısında, ölçme ve değerlendirme tekniklerinde, genel olarak yapılandırmacı anlayışın yer aldığı, öğrenci merkezli ve etkinlik temelli uygulanmasına önem verildiği görülmektedir (Eskicumalı, Demirtaş, Erdoğan ve Arslan, 2014). Diğer ülkelerle karşılaştırıldığında Türkiye'deki öğrencilerin TIMSS-R (Third International Mathematics and Science Study) ve PISA (Programme for International Student Assessment) gibi uluslararası sınavlarda fen bilimleri ve matematikteki başarılarının çok düşük olması program değişikliğinin nedenleri arasında gösterilmektedir (Kılıç, 2002). Öğrencilerin tutumlarının (Akpınar, Yıldız, Tatar ve Ergin, 2008; Çakır, Şenler ve Taşkın, 2007) ve sorgulama becerilerinin (Altun, Feyzioğlu ve Demirdağ, 2011) sınıf düzeyi ilerledikçe düşmesi, derslerin öğretmen merkezli yapısı ve içeriğin yoğunluğu (Aksit ve Sands, 2006, s.20; Inozu, 2011; Ünal ve Akpınar, 2006) da program değişikliğinin gerçekleşmesinde yer alan gerekçelerdir. Ayrıca 2004-2005 öğretim yılından önce uygulanmakta olan programın öğrenciyi ezberleyerek öğrenmeye yönelttiği ve bu nedenle öz güven, eleştirel düşünme, yaratıılık ve zorluklara başa çıkma becerilerini geliştirmede yetersiz kaldığı belirtilmektedir (Gür, Çelik ve Özoğlu, 2012).

Türkiye'de 2005 yılında değişen fen programının yapılandırmacı yaklaşımı benimsediği belirtilmektedir (Milli Eğitim Bakanlığı, MEB, 2005). 2013 yılında güncellenen programda ise, öğrenenin kendi öğrenmesinden sorumlu olduğu, öğrenme sürecine aktif katılımının sağlandığı ve bilgiyi kendi zihninde yapılandırmaya olanak tanıyan araştırma-sorgulamaya dayalı öğrenme stratejisinin benimsendiği belirtilmiştir (MEB, 2013). Yapılandırmacı öğrenme kuramının hem 2005 yılı programında hem de 2013 yılı programında yer aldığ bununla birlikte, 2013 yılı programında araştırma-sorgulama becerilerinin bir adım daha öne çıktığı söylenebilir. Öğrencilerin bu becerileri edinebilmeleri için, bilimsel açıklamaları anlayabilmeleri, bilimsel veri oluşturabilmeleri, öğrendikleri bilimsel bilgiyi sunabilmeleri ve bilime nitelikli katılım sağlayabilmeleri gereklidir (NRC, 2011). Ayrıca 2013 yılında yenilenen Fen bilimleri dersi öğretim programının temel ilkeleri arasında bilgi alanında içerik kazanımlarına, beceri alanında bilimsel süreç ve yaşam becerilerine yer verildiği görülmektedir. Duyuşsal alanda motivasyon, tutum, değerler ve sorumluluk kazanımlarına, fen-teknoloji-toplum-çevre alanında ise bilimin doğasına, sosyo-bilimsel konulara, kariyer bilincine, bilimin teknoloji ve toplumsal kalkınma ile ilişkisine yer verilmiştir. Bütün bu değişimler birlikte incelendiğinde, programın öğrenme ve öğretme anlayışını sınıflara yansıtacak olan öğretmenlerin rolü bir kez daha öne çıkmaktadır. Bu doğrultuda programların yenilenme çalışmalarına paralel olarak MEB tarafından Fen ve Teknoloji Öğretmeni Özel Alan Yeterlilikleri belirlenmiş ve yayınlanmıştır (MEB, 2008). Hem programda hem de öğretmen yeterliklerinde belirtilen bu köklü değişimler, öğretmenlerin değişim sürecine ne düzeyde ayak uydurabildiklerini yani değişimi ne düzeyde özümsediklerini belirlemeyi gerekli kılmaktadır. Öğretmenlere göre sürekli değişen eğitim-öğretim programı fen öğretimini olumsuz yönde etkilemektedir (Akınc1, Uzun ve Kışoğlu, 2015). Her ne kadar, programda sunulan öğrenme ve öğretme yaklaşımlarının farkında olsalar da, öğretmenlerin sınıflarında anlatım yöntemini kullanmayı daha çok tercih ettikleri ve bu yöntemi soru-cevap, gösteri ve örnek olay yöntemi ve problem çözme yöntemleri ile destekledikleri belirlenmiştir (Karamustafaoğlu, Bayar ve Kaya, 2014). Bunun da ötesinde, öğretmenlerin 2013 Fen Bilimleri öğretim programının yapılandırmacı öğrenme teorisinin yanı sıra araştırma sorgulamaya 
dayalı öğretim yaklaşımına uygun olduğunun farkında olmadıkları tespit edilmiştir (Karamustafaoğlu, Salar ve Celep, 2015). Sonuç olarak reform çalışmalarıyla ders programı yenilenmiş ve buna paralel olarak öğretmen yeterlilikleri belirlenmiş olsa da öğretmenlerin pedagojik alan bilgilerinin yetersiz olması reform çabalarının başarısızlıkla sonuçlanmasına neden olabilir.

\section{Fen Öğretimi Yönelimi}

Öğretmenin öğretmek için neleri bilmesi gerektiği Shulman (1986) tarafindan "Pedagojik Alan Bilgisi (PAB)" olarak tanımlanmıştır. PAB, bir öğretmenin konu alan (içerik) bilgisi ve pedagojik bilgisinin özel bir boyutu olarak tanımlanmaktadır. Bu çalışmada PAB'ın alt boyutlarından biri olan alan öğretiminin bir unsuru olarak öğretim yönelimi üzerinde durulmuştur. Anderson ve Smith (1987, s.99), fen öğretimine yönelik öğretmen yönelimini "fen öğretimi ve öğrenimi ile ilgili genel düşünce ve davranış desenleri" olarak tanımlamıştır. Grosman (1990) ve Magnusson, Krajcik ve Borko (1999) tarafından ise öğretmenlerin "belirli bir sınıf seviyesinde fen öğretimi amaç ve hedefleri hakkındaki bilgileri ve inanışları" olarak tanımlanmıştır. Lotter, Harwood ve Bonner (2007) fen bilgisi öğretmenlerinin öğretim yönelimlerinin sorgulamaya dayalı öğretime yönelik sahip olduğu kavramları, araştırma sorgulamaya ayırdıkları zamanı, bunun düzeyini ve kullandıkları öğretim yöntemlerini etkilediğini belirtmişlerdir.

Öğretmenlerin fen öğretimi yönelimlerini tanımlamak için bir dizi kategori geliştirilmiştir. Örneğin Anderson ve Smith (1987, s.99), öğretim yönelimlerini doğrudan öğretim, etkinlik odaklı öğretim, keşfederek öğretim ve kavramsal değişim öğretimi olarak dört kategoride tanımlamışlardır. Magnusson ve diğ. (1999), fen öğretimine yönelik yönelimleri süreç, akademik katılık, didaktik, kavramsal değişim, etkinlik odaklı, keşfedici, proje tabanlı, sorgulama ve rehberli sorgulama olarak kategorilendirmişlerdir. Öğretim yöneliminin, öğrenme amaçları, programın uygulanması ve öğrenmelerin değerlendirilmesi ile ilgili kararlara rehberlik ettiğini belirtmişlerdir. Friedrichsen'e (2002) göre öğretim yönelimleri hem merkezi hem de çevresel amaçları kapsar. $\mathrm{Bu}$ amaçlar ise öğretilen konu ve öğrencilerin sınıf düzeyi ile birlikte değişebilir. Ders içeriği ve öğrencilerin yeteneklerindeki farkl1lıklar öğretime yönelik yönelimleri etkilemektedir. Buna göre, ileri düzeyde bir dersin öğretimi için öğretmen yönelimi aynı öğretmenin normal düzeydeki bir dersinden farklılık gösterebilir. Bu nedenle ise öğretim yönelimlerini öğretmen merkezli öğretim ve ders programıyla ilgili ve reform çabalarına dayanan yenilikçi yaklaşım olarak iki ana kategoride gruplamışır.

2013 yılında yenilenen Fen Bilimleri dersi programının uygulanmasında öğretmenlere 3. ve 4. sınıflarda yapılandırılmış araştırma-sorgulama, 5. ve 6. sınıflarda rehberli araştırma-sorgulama ve 7. ve 8. sınıflarda ise açık uçlu araştırma-sorgulama yaklaşımı önerilmiştir (MEB, 2013). Yapıllandırılmış araştırmadan açık uçlu araştırma sorgulama yaklaşımına geçildikçe, öğrenci araştırmanın bölümlerini giderek kendisi gerçekleştirir hale gelmektedir. Programda belirtilen bu yaklaşımların, Cobern ve diğ. (2014)'ün doğrudan öğretim, aktif doğrudan, yapılandırılmış sorgulayıcı ve yapılandırılmamış buluş olmak üzere önerdiği dört farklı öğretim yönelimi sınıflamasıyla benzerlikler gösterdiği söylenebilir. Bu nedenle bu çalışmada öğretmenlerin öğretim yönelimleri Cobern ve diğ. tarafindan belirlenen kategorilere göre incelenmiştir. Doğrudan öğretim yaklaşımında öğretmen bilimsel kavramları, yasaları veya kuramı öğrenciye doğrudan verir ve açıklar. Düzeltici geri bildirimlerde bulunur (Whyte ve Ellis, 2003). Bir örnekle ya da sunumla açıklama yapar. Öğrenci aktif değildir. Ancak öğretmen öğrencilerden konuya ilişkin soru alır ve bu sorulara açıklık getirir (Donovan ve Bransford, 2005). Aktif doğrudan öğretim yaklaşımında, doğrudan öğretim yaklaşımında olduğu gibi bilimsel kavramlar, yasalar ve kuram öğretmen tarafindan doğrudan verilir. Öğretmen bir sunum ve örnekle açıklama yapar. Bu yaklaşımın doğrudan öğretim yaklaşımından farkı bilginin aktarımından sonra bilimsel sunuma dayalı öğrenci aktivitelerinin yer almasıdır. Öğrenme ortamı öğretmenin bilgiyi aktarmasını kolaylaştıracak şekilde düzenlenmektedir (Thomas ve dĭg., 2001). Bu yaklaşımda öğrenciler öğretmenin aktardığı yasayı doğrulayıcı uygulamalar yaparlar. Bu sınıflarda öğrencilerden beklenen öğretmen tarafindan 
sunulan bilgilerin tekrarlanması ve hatırlanmasıdır (Billings, 2001; Cobern ve diğ., 2014). Yapılandırılmış sorgulayıcı yaklaşımda konular bilgi ve olguların öğrenciler tarafından keşfetmesi ile ilerler. Öğretilecek konu, kavram merkezdedir ve bu kavramı öğrenmeye yönelik etkinlikler tasarlanır. Öğretmen etkinliklerle bilimsel yasa ve kavramların ortaya çıkması için rehberlik yapar. Öğrenciler öğretmenin yönlendirmesiyle gerekirse küçük gruplar halinde aktiviteler yaparlar ve kendi aralarında tartışma firsatı bulurlar. Öğretmen ayrıca konuları açıklamak ve pekiştirmek için örnekler verebilir (Whyte ve Ellis, 2003; Cobern ve diğ., 2014). Yapılandırılmamış buluş yaklaşımında öğretmen öğrencilerin ilgi, istek ve kararlarını ön planda tutar. Etkinlikler öğrencilerin sorularından yola çıkarak belirlenir (Whyte ve Ellis, 2003). Öğrenci olguları ve yasaları kendi tasarladığı bilimsel yollarla açıklar. Öğretmen öğrencilerin belirlediği ve tasarladığı süreci kolaylaştırır ancak bu sürece aktif katılmaz. Sorgulama süreci en önemli hedef olarak kabul edilir. Öğrenciler ne yaptıklarını ve ne keşfettiklerini sunarlar (Cobern ve diğ., 2014).

Fen öğretimi yöneliminin konu alanı bilgisine göre değerlendirildiği Ramnarain, Nampota ve Schuster (2016)'ın çalışmasına göre, öğretmenlerin yönelimleri aktif doğrudan ve yapılandırılmış sorgulayıcı arasında yer almaktadır. Başka bir çalışmada ise doğrudan öğretime göre yapılandırılmamış buluş yönelimini tercih eden öğretmenlerin 5E öğrenme döngüsünü daha fazla uyguladıkları belirlenmiştir (Lakin ve Wallace, 2015). Samuelowicz ve Bain (2001) öğretim yönelimlerinin öğretmenlerin öğretim ve öğrenme için hedef ve amaçlar ile ilgili olduğunu belirtmişlerdir. Çalışmalarında öğrencilerin kavramları anlamasını artırma amacında olan öğretmenlerin öğretmen merkezli stratejiler üzerine odaklandığını, amaçlarını öğrencilerin içerik ile ilgili uzmanlığının geliş̧imini desteklemek olarak tanımlayan öğretmenlerin ise öğrenci merkezli stratejileri uyguladığını belirtmişlerdir. Benzer şekilde Wongsopawiro (2012)'nun çalışmasına göre, doğrulama veya yapılandırılmış düzeyde araştırmalar planlayan öğretmenler didaktik veya etkinlik temelli yani öğretmen merkezli öğretim yönelime sahiptirler. Bu durumda öğretmenler, düşük düzeylerde araştırmalar uygulamalarına rağmen hem öğretmen merkezli hem de öğrenci merkezli araştırmalar yürütebilmektedirler. Aynı araştırmaya göre hem öğretmen merkezli hem de öğrenci merkezli yönelime sahip öğretmenler, öğrencilerin alan bilgilerindeki ve araştırma becerilerindeki eksikliklere vurgu yaparken öğrenci merkezli yönelimdeki öğretmenler araştırma ile öğrencilerin günlük yaşantıları arasındaki ilişkilere vurgu yapmaktadırlar. Öğretmenlerin yönelimleri önceki öğrenme yaşantılarıyla ilişkilendirilirken, öğrenmeyle ilgili görüşlerini ve öğretimle ilgili planlarını ve uygulamalarını etkileyebilmektedir. Brown (2008), öğretim sırasında bilginin aktarıldığı ve kendilerine pasif bir rol verilen öğretmenlerin hizmet içi eğitim programlarına katılsalar bile bu rollerinin değişmeye karsı direnç gösterdiğini belirtmektedir.

\section{Öğretmenlerin Yönelimlerini Etkileyen Unsurlar}

Öğretmenlerin bireysel özelliklerinin ve fiziksel koşulların fen öğretimi yönelimlerinin biçimlenmesinde rolünün olduğu öne sürülmektedir. Bireysel özellikler arasında cinsiyet ve mesleki kıdem yer alırken sinıf düzeyi, okulun fiziksel koşulları ve görev yeri unsurları ise fiziksel özellikler arasında gösterilmektedir. Bu özellikler, aynı öğretmenin değişik öğretim yönelimleri sergilemesine neden olabilmektedir. Örneğin Friedrichsen ve Dana (2005), öğretmenlerin farklı sınıflarda aynı yönelimden ziyade farklı yönelimler gösterdiklerini ve yönelimlerinin merkezi ve harici amaçlarına göre biçimlenen bir yapıda olduğu belirtilmektedirler. Öğretmenlerin merkezi amaçları alan yazında daha önce açıklanan kategorilere göre isimlendirilirken (akademik katılık, didaktik vb.), bilime yönelik olumlu tutumların geliştirilmesi ve sürdürülmesi, öğrencilerin merak etme duygularının geliştirilmesi, bilinçli ve sorumlu birer yurttaş olmaları, hem okul hem de günlük hayatlarında başarılı olmaları gibi harici amaçlara da sahip olabilmektedirler. Öte yandan öğretmenler öğrencilere fen öğrenmeleri için rehber olmak gibi "ideal” yönelimlere sahipken sınıfta içeriğin aktarılması ve öğrenci merkezli olmayan fen uygulamaları yaptırmak şeklinde "işleyen” yönelimlere de sahip olabilmektedir (Koballa, Glynn, Upson ve Coleman, 2005). Avraamidou (2013)'nun çalışmasına katılan öğretmenler ise üniversitede aldıkları fen öğretimi dersinin öğretim yönelimlerini etkileyen en önemli unsur olduğunu belirtmişlerdir. Öğretmenler üniversiteye başlamadan önce fene yönelik olumsuz tutumlara 
sahipken bu derste rehberli araştırma düzeyinde deneyler yaptıkları, öğrendikleri bilgileri okullarda uygulayabildikleri için bu dersin eğlenceli ve ilgi çekici olduğunu belirtmişlerdir. Ayrıca öğretmenlerin yönelimleri sınıf mevcudu ve ölçme-değerlendirme sistemi nedeniyle fen programının yöneliminden uzaklaşabilmektedir. Örneğin Nargund-Joshi, Rogers ve Akerson (2011)'a göre öğretmenler öğrencilerinin meslek seçimlerinde önemli bir basamak olarak gördükleri seviye belirleme sınavından aldıkları puanlara yönelik yüksek bir sorumluluk hissetmektedirler. Bu nedenle öğretmenler ders kitabını bir otorite olarak görürken, öğrencilerin pasif bilgi alıcısı olduğunu, laboratuvarın amacını öğrencilerin bilgiyi keşfetmek veya uygulamaktan ziyade önceden açıklanan bilginin doğrulanması olarak gördüklerini belirtmişlerdir

$\mathrm{Bu}$ çalışmanın konusu olan cinsiyet değişkeni, pek çok öğretmenin henüz öğretmen adayı iken geliştirdiği bir olgu olabilmektedir. Öğretmen adaylarının öğrenme ve öğretme anlayışlarının cinsiyetlerine göre değişmesi bu olguyu kanıtlar niteliktedir (Aydın, Tunca ve Şahin, 2015). Ağgül-Yalçın (2011)'a göre bayan öğretmen adayları fen öğretimine yönelik olarak kendilerine daha çok güvenme, yeterli görme ve öğretimin niteliğini artırmak için üst düzey çaba gösterme eğiliminde olabilmektedirler. Benzer şekilde bayan öğretmen adaylarının öğrenci merkezli öğretim yöntemlerini kullanmakta erkek öğretmen adaylarına göre daha istekli oldukları belirlenmiştir (Elmas, Demirdöğen ve Geban, 2011). Bu durum, bayan öğretmenlerin bilgiyi aktaran bir rolden ziyade öğrencilere rehber, yardımcı veya bir kaynak olan bir öğretim stilini benimsemelerinden kaynaklanıyor olabilir (Nelson-Laird, Garver, Niskode ve Chang, 2007). Araştırmada ele alınan bireysel özelliklerden mesleki kıdem, öğretmenlerin öğretime ve öğrencinin rolüne yönelik görüşlerini etkileyebilmektedir. Hoy ve Woolfolk (1989)'a göre öğretmenin tecrübesi arttıkça, öğrenciye öğrenmesi için daha fazla sorumluluk vermekte ve bu da sınıfta öğretmenin rehber olarak görüldüğü bir öğrenme ortamının sağlanmasına yardımcı olmaktadır. Öte yandan, deneyimli öğretmenler söz konusu olsa da, öğretmenler programın önerdiği öğretim yöntemlerini kendilerine göre değiştirebilmektedirler. Örneğin Tseng, Tuan ve Chin (2013)'un çalışmasına katılan öğretmenlerin bazıları mesleki kıdemleri yüksek olsa bile, programda önerilen içerik bilgisinin öğretimine odaklanırken, bazı öğretmenler öğrencilerinin anlamlı öğrenmesi yönünde bir öğretime odaklanmaktadırlar. Ayrıca öğretmenlerin mesleki yaşantıları arttıkça derslerinde anlamlı öğrenmeyi sağlayan öğretim materyallerini daha sık kullanmaları beklenirken, mesleki kıdemleriyle materyal kullanım sıklığı arasında anlamlı bir ilişkinin olmadığını gösteren çalışmalar mevcuttur (Karamustafaoğlu, 2004; Şahin, 2015). Öğretmenlerin hizmet puanları nedeniyle mesleki kıdemleri ile görev yaptıkları yer arasında bir ilişki olduğu düşünüldüğünde, il merkezindeki öğretmenlerin ilçe merkezindeki öğretmenlere göre kendilerini geliştirmek, araştırma yapmak ve mesleki açıdan daha yeterli duruma gelebilmeleri için sahip oldukları olanakların daha fazla olabileceği belirtilmektedir (Akçil ve Oğuz, 2015). Örneğin köy okullarında görev yapan öğretmenler, program yenilendikten sonra kendilerine sunulan hizmet içi eğitim olanaklarının yeterli olmadığını düşünmektedirler (Yapıcı ve Leblebiciler, 2007). Bu çalışmalar öğretmenlerin görev yaptıkları okulun imkanlarının öğretim yönelimi üzerine etkisine örnek olarak gösterilebilir. Okul yapısının öğretmenlerin öğretime yönelik yönelimlerini etkilediği dikkate alınırsa yönelimleri belirlemek öğretmenlerin görev yaptıkları kurum hakkında da genel olarak fikir sahibi olunmasını sağlayacaktır.

\section{Araştırmanın Önemi ve Amacı}

Programda belirtilen hedeflere ulaşılmasında öğretmenlerin yönelimleri önemli rol oynamaktadır. Program 2013 yılında yenilenmiş olsa bile bu programdaki hedeflere uygun olarak öğretmenlerin yönelimlerini değerlendiren yeterince çalışma bulunmamaktadır. Yenilenen programı dikkate alarak öğretmenlerin öğretim yönelimlerini belirlemek, okullarda programın ne düzeyde uygulanmış olduğuna ve öğretmen yeterliliklerinin ne durumda olduğuna ilişkin bilgi sağlayacaktır. $\mathrm{Bu}$ araştırmanın amacı, Fen Bilimleri öğretmenlerinin fen öğretimi yönelimlerini belirlemek, bu yönelimlerin cinsiyet, mesleki kıdem ve görev yerine göre nasıl değiştiğini ortaya çıkarmaktır. Araştırmada ele alınan araştırma soruları aşağıda belirtilmiştir: 
1. Fen Bilimleri öğretmenlerinin fen öğretimi yönelimleri nasıldır?

2. Fen Bilimleri öğretmenlerinin cinsiyetlerine göre fen öğretimi yönelimleri arasında anlamlı bir farklılık var midır?

3. Fen Bilimleri öğretmenlerinin mesleki kıdemlerine göre fen öğretimi yönelimleri arasında anlamlı bir farkl111k var mıdır?

4. Fen Bilimleri öğretmenlerinin görev yerlerine göre fen öğretimi yönelimleri arasında anlamlı bir farklılık var mıdır?

\section{Yöntem}

Araştırma, Fen Bilimleri öğretmenlerinin fen öğretimi yönelimlerini belirlemeyi amaçlamaktadır. Öğretmenlerin var olan durumu betimlenmeye çalışıldığı için araştırma tarama modelinde yürütülmüştür (Cohen, Manion ve Morrison, 2000).

\section{Çalışma Grubu}

Araştırmanın çalışma grubunu, Aydın il merkezinde ve ilçelerinde görev yapan Fen Bilimleri öğretmenleri oluşturmaktadır. Örneklem seçiminde kolay ulaşılabilir durum örnekleme yöntemi kullanılmıştır. Bu yöntemde araştırmacı yakın olan ve erişilmesi kolay olan bir örneklem üzerinde çalışır (Yıldırım ve Şimşek, 2008). Ancak bu örnekleme tekniği, evrendeki her popülasyonun örneklemde temsil edilememesi ve elde edilen sonuçların daha geniş bir örneklem için genelleme yapılmasına olanak tanımaması sınırlıklarına sahiptir (Krishnaswamy ve Ranganathan, 2010). İl merkezinde bulunan okullarda görev yapan öğretmenlerden ulaşılabilir veya kolay iletişim kurulabilir olan 95 öğretmene ulaşılmıştır. Çalışma grubunun demografik özellikleri Tablo 1'de sunulmuştur.

Tablo 1. Çalışma Grubunun Demografik Özellikleri

\begin{tabular}{llll}
\hline & & $\mathrm{N}=95$ & $\%$ \\
\hline Cinsiyet & & $\mathrm{N}$ & 45 \\
\multirow{3}{*}{ Mesleki Kidem } & Bay & 43 & 55 \\
& Bayan & 52 & 48 \\
& $1-10$ y1l & 46 & 33 \\
Görev yeri & $11-20$ yil & 31 & 19 \\
& 21 ve üstü & 18 & 41 \\
& İl merkezi & 39 & 59 \\
\hline
\end{tabular}

\section{Veri Toplama Arac1}

Öğretmenlerin fen öğretimi yönelimlerini belirlemek amacıyla Schuster ve dĭ̆. (2007)'nin geliştirdiği Fen Öğretimi Eğitsel Yaklaşım Testi (FÖEYT, Pedagogy of Science Teaching Test) kullanılmıştır. FÖEYT'nin Türkçeye uyarlaması Güvenç ve Sert (2013) tarafından yapılmıştır. Testte 16 madde bulunmaktadır. Bu maddeler "Yer Bilimi”, "Yaşam Bilimi”" ve "Fizik Bilimi”" alanlarına dağılmıştır (Schuster ve diğ., 2007). Güvenç ve Sert, çalışmalarında testin öğretmenlerin eğitsel yaklaşımlarını belirlediğini belirtmişlerdir. Bu çalışmada, eğitsel yaklaşım yerine öğretim yönelimi terimi tercih edilmiştir. Schuster ve diğ. (2007)'nin geliştirdiği fen öğretimi yönelimi spektrumuna göre eğitsel yaklaşım, belirli bir konuyu öğretmek için öğretmenin tasarımı ve uygulamasıyla ilgili verdiği karar olarak tanımlanmaktadır. Bu durumda eğitsel yaklaşım terimi, öğretmenin öğrenme ve bilgiyle ilgili amacını yansıtırken, testte yer alan maddelere verilen yanıtlar, öğretmenin belirli bir konu ve sınıf düzeyine göre yöntem seçimini yansıtmaktadır. Her test maddesinin yapısı biçimsel olarak Şekil 1'de sunulmuştur. 


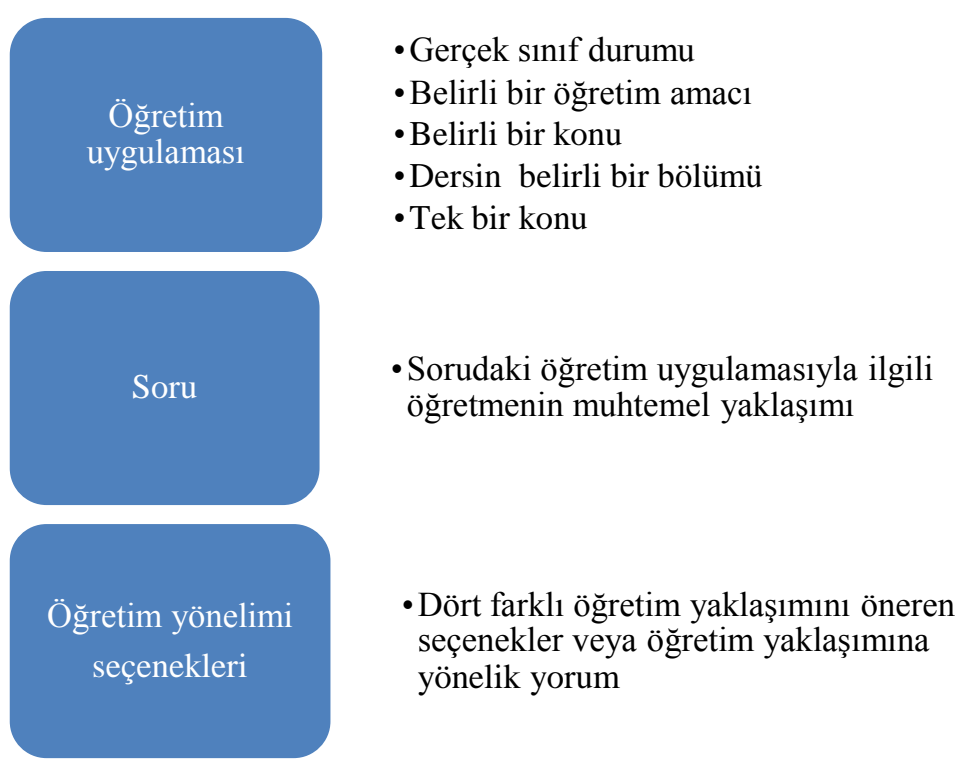

Şekil 1. Her Test Maddesinin Biçimsel Yapısı (Schuster ve diğ. (2007)'den alınmıştır).

Şekil 1'de görüldüğü gibi, her test maddesi, öğretmenin sınıfta karş1laşabileceği gerçek bir öğretim uygulamasını gösteren, belirli bir konu ile ilgili kısa bir olay ile başlamaktadır. Bu olaydan sonra öğretmene derse nasıl devam edeceği veya dersi nasıl farklı bir şekilde nasıl işleyeceği sorulmaktadır (Schuster ve diğ., 2007). Her madde cevaplanırken öğretmene dört seçenek sunulmaktadır. Bu seçenekler doğrudan öğretim, aktif doğrudan, yapılandırılmış sorgulayıcı ve yapılandırılmamış buluş olmak üzere dört farklı yönelimi temsil etmektedir (Lakin ve Wallace, 2015). Seçeneklerden doğrudan öğretim ve aktif doğrudan yaklaşımları, temel bilgi kuramını bilimin olgusal bilgi olarak sunulduğu hazır bilgi olarak ele almaktadır (Cobern ve diğ., 2014). Doğrudan öğretim yaklaşımında öğretmen içeriği doğrudan sunar ve açıklar. Konuyu örneklerle ve gösteri deneyleriyle anlatır. Öğrenci derse katılmaz (Cobern ve diğ., 2014). Aktif doğrudan yaklaşımında, doğrudan öğretim yaklaşımında olduğu gibi öğretmen içeriği doğrudan sunar ve açıklar. Bununla birlikte öğrenci öğretmenin önceden açıkladığı bir teorinin doğrulanmasıyla meşgul olur (Cobern ve diğ., 2014). Yapılandırılmış sorgulayıcı ve yapılandırılmamış buluş yaklaşımlarına göre ise bilim, bilimsel araştırma süreçleri sayesinde gelişir ve hazır bilgi değil yapılmakta olan bilgi şeklindedir (Cobern ve diğ., 2014). Yapılandırılmış sorgulayıcı yaklaşımında öğrenci önceden belirlenmiş bir bilimsel içeriği öğrenmek için öğretmenin rehberliğinde bir olguyu ya da bir fikri keşfetmeye çalışır. Yapılandırılmamış buluş yaklaşımında ise öğrenci kendi belirlediği bilimsel içeriği öğrenmek için öğretmenin rehberliğinde bir olguyu ya da fikri keşfetmeye çalışır (Cobern ve diğ., 2014). Bu araştırmada, FÖYT'deki her bir maddeden sonra öğretmenlere seçeneği işaretlemelerinin gerekçesi sorulmuştur. Bu sayede, öğretmenlerin öğretim yönelimlerinin hangi unsurlara göre değiştiği belirlenmeye çalışılmıştır. FÖEYT'nin daha iyi anlaşılması için Şekil 2'de örnek bir madde sunulmuştur. 


\section{1 - Kuvvet ve Hareket Hakkanda Ders}

Zehra Ögretmen, 5. sinıf ögrencilerine kuvvet ve hareket arasındaki ilişkiyi; yani cisme etki eden net kuvvetin cismin hızlanmasına ya da yavaşlamasına yol açacağını (Newton'un 2. Kanunu) gösteren bir ders hazırlamaktadir. Sinıfta, cekme kuvvetinin goy Öğvetmen, ders konusunda dört farklı yaklaşım düşünmektedir.

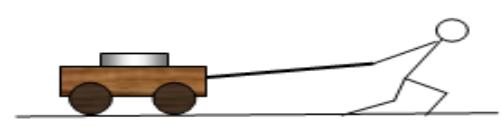

Bu dersi nasıl işlemek istediğinizi düşündüğünüzde, aşağıdakilerden hangisi yapacaklarınıza en yakın olanıdır?

A. Newton'un 2. Kanunu'nun açık bir ifadesini tahtaya yazardım ve bunu ögrencilerime dikkatlice açıklardım. Bunun ardından yüklü bir vagonu gözlem yapan sınıfın önünde sabit bir kuvvetle çekerek kanunu gösterirdim.

B. 'Sabit kuvvet nasıl bir harekete yol açar?' sorusunu yöneltirdim. Bunun ardından öğrencilerimi yüklü vagonu çekme ve bunu gözlemleme yoluyla soruyu tek başlarına incelemeye yönlendirirdim. Kanıttan vagonu çekme ve bunu gözlemleme yoluyla so

C. Newton'un 2. Kanunu'nun açık bir ifadesini tahtaya yazardım ve bunu ögrencilerime dikkatlice açıklardım. Bunun ardından öğrencilerimi yüklü vagonu tek başlarına çekmeye ve ne tür bir hareketin ortaya çıktığını görmeye yönlendirerek kanunu doğnulamalarını sağlardım.

D. Kuvvet ve hareket arasında herhangi bir ilişkinin bulunup bulunmadığı sorusunu yöneltirdim. Bunun ardından ögrencilerimi, bunu laboratuvarda güvenli bir şekilde inceleme konusunda serbest bırakırdım. Bunu bulgular konusunda sınıf içi bir tartışma takip ederdi.

Şekil 2. FÖEYT'den Örnek Bir Madde (Güvenç ve Sert (2013)’ten alınmıştır).

Güvenç ve Sert (2013) FÖEYT'nin Cronbach's Alpha iç tutarlık katsayısını .74 olarak bulmuşlardır. Ayrıca, alt ve üst (\%27) grupta yer alan katılımcıların ortalamalarının karşılaştırıldığı bağımsız t testi sonuçları, ortalamalar arası farkın bütün maddeler için anlamlı olduğunu göstermiştir. $\mathrm{Bu}$ araştırmada, testin Cronbach's Alpha iç tutarlık katsayısı .74 olarak bulunmuştur. Ayrıca bu çalışmada da alt ve üst (\%27) grupta yer alan katılımcıların ortalamalarının karşılaştırdıkları bağımsız $\mathrm{t}$ testi sonuçları, ortalamalar arası farkın bütün maddeler için anlamlı olduğunu göstermiştir. Araştırmada öğretmenlerin FÖEYT'den aldıkları puanlara göre aritmetik ortalamaları belirlenmiş, bu ortalamalara göre ortaya çıkan öğretim yönelimleri dikkate alınarak dört öğretmenle görüşmeler yapılmış ve bu seçeneği neden işaretledikleri sorulmuştur. $\mathrm{Bu}$ öğretmenler Ö1, Ö2,...̈̈4 şeklinde kodlanmıştır.

\section{Verilerin Analizi}

FÖEYT'deki her madde için verilen seçenekler doğrudan öğretim, aktif doğrudan, yapılandırılmış sorgulayıcı ve yapılandırılmamış buluş olmak üzere dört farklı yönelimi temsil ettiğinden bu yönelimlere sirasiyla 1, 2, 3 ve 4 puanları verilerek, testin her maddesine ait aritmetik ortalama ve standart sapma betimsel istatistikleri hesaplanmıştır. Elde edilen aritmetik ortalamalar ile öğretim yönelimleri arasında bir ilişkinin kurulması için, her yönelime ait aralık genişliği hesaplanmıştır. Bunun için öncelikle testin ranjı hesaplanmıştır. Bir maddeden alınacak en düşük puan 1, en yüksek puan 4 olduğundan, ranj 3'tür. Testin cevapları dört grup olduğundan grup sayısı 4'tir. Ranjın grup sayısına bölünmesiyle ise puan aralığının açıklığı belirlenmiştir yani 3/4=0,75'tir. Her bir öğretim yöneliminin puan aralığı Tablo 2'de gösterilmiştir. Ayrıca test 16 maddeden oluştuğu için her seçenek için belirlenen aralık genişliği 16 ile çarpılarak testin tamamı için aralık genişliği de belirlenmiştir.

Tablo 2. FÖEYT'nin Her Seçeneği ve Testin Tamamı İçin Öğretim Yönelimi Puan Aralı̆̆

\begin{tabular}{lll}
\hline & Aralık Genişliği & Öğretim yaklaşımı \\
\hline Her Seçenek İçin & Testin Tamamı İçin & \\
$1.00<\mathrm{x}<1.74$ & $16.00<\mathrm{x}<27.84$ & Doğrudan öğretim \\
$1.75<\mathrm{x}<2.49$ & $28<\mathrm{x}<39.84$ & Aktif doğrudan \\
$2.50<\mathrm{x}<3.24$ & $40<\mathrm{x}<51.84$ & Yapılandırılmış sorgulayıc1 \\
$3.25<\mathrm{x}<4.00$ & $52<\mathrm{x}<64.00$ & Yapılandırılmamış buluş \\
\hline
\end{tabular}


Tablo 2'de sunulan puan aralığına göre, öğretmenlerin yönelimlerinin gerekçeleri doğrudan betimlenerek sunulmuştur. Fen Bilimleri öğretmenlerinin cinsiyetlerine, mesleki kıdemlerine ve görev yerlerine göre FÖEYT'den aldıkları puanların homojenliğinin belirlenmesi için varyansların homojen dağılıp dağılmadığı incelenmiştir. Cinsiyet ve mesleki kıdem için gruplar arasında homojen dağılım varken (sırayla $\mathrm{p}=.243, \mathrm{p}=$ $.086>.05)$ görev yerine göre gruplar arasında homojen dağılım yoktur $(\mathrm{p}=.011, \mathrm{p}=<.05)$. Bu nedenle cinsiyet ve mesleki kıdem değişkenleri için sırayla $t$ testi ve tek yönlü varyans analizi (ANOVA) kullanılırken, görev yeri için Mann Whitney U-Testi kullanılmıştır.

\section{Bulgular}

$\mathrm{Bu}$ bölümde, ilk olarak Fen Bilimleri öğretmenlerinin fen öğretimi yönelimleri sunulmuş, cinsiyet, mesleki kıdem ve görev yeri olarak belirtilen değişkenlerin öğretmenlerin yönelimleri üzerindeki etkisine ilişkin bulgulara yer verilmiştir. Her bağımsız değişkene ilişkin elde edilen bulgular ayrı ayrı tablolarda sunulmuş ve yorumlanmıştır.

Fen Bilimleri Öğretmenlerinin Fen Öğretimi Yönelimleri

Teste verilen yanıtlar incelenirken öncelikle, her test maddesinin öğretim yönelimlerine göre frekans ve yüzde dağılımı incelenmiştir (Tablo 3, Şekil 3). Daha sonra öğretmenlerin hangi test maddesinde en yüksek yönelim yüzdesine sahip oldukları belirlenmiş ve sadece bu maddeler yorumlanmıştır. Buna göre Işık Yansıması maddesi incelendiğinde, en yüksek yüzdeliğin doğrudan öğretim yöneliminde olduğu görülmektedir. Öğretmen bilimsel bir kanunu açıklayarak derse başlamakta ve şema çizerek veya örnek vererek kanunu daha anlaşılır hale getirmektedir. Verilen örnek uygulamalı bir çalışmayı göstermekle birlikte öğrencilerin öğrendikleri kanunu doğrulayıcı niteliktedir.

Tablo 3. Her Test Maddesinin Öğretim Yönelimlerine Göre Frekans ve Yüzde Dağılımı

\begin{tabular}{|c|c|c|c|c|c|c|c|c|}
\hline \multirow[t]{2}{*}{ Test maddesinin adr $^{4}$} & \multicolumn{2}{|c|}{ DÖ } & \multicolumn{2}{|c|}{$\mathrm{AD}$} & \multicolumn{2}{|c|}{ YS } & \multicolumn{2}{|c|}{ YB } \\
\hline & $\mathrm{f}$ & $\%$ & $\mathrm{f}$ & $\%$ & $\mathrm{f}$ & $\%$ & $\mathrm{f}$ & $\%$ \\
\hline Kuvvet ve Hareket Hakkında Ders & 5 & 5 & 23 & 24 & 34 & 36 & 33 & 35 \\
\hline Dünyanın Dönüşü & 10 & 11 & 43 & 45 & 11 & 12 & 31 & 33 \\
\hline Hava Maddedir & 13 & 14 & 10 & 11 & 60 & 63 & 12 & 13 \\
\hline Ünitenin Genel Özeti & 16 & 17 & 38 & 40 & 22 & 23 & 19 & 20 \\
\hline Yapı ve İşlev & 7 & 7 & 22 & 23 & 52 & 54 & 16 & 16 \\
\hline Saha gezisi & 18 & 19 & 8 & 8 & 31 & 33 & 38 & 40 \\
\hline Av ve Avc1 & 30 & 32 & 12 & 13 & 24 & 25 & 29 & 31 \\
\hline Organizma, Çevreye Tepki Gösterir. & 10 & 11 & 26 & 27 & 45 & 47 & 14 & 15 \\
\hline Toprak Geçirgenliği & 18 & 19 & 14 & 15 & 22 & 23 & 41 & 43 \\
\hline Kurbağa Diseksiyonu & 14 & 15 & 7 & 7 & 52 & 55 & 22 & 23 \\
\hline Yağmur ve Su Akış1 & 6 & 6 & 20 & 21 & 57 & 60 & 12 & 13 \\
\hline Miknatıslar ve Materyaller & 28 & 29 & 27 & 28 & 18 & 19 & 22 & 23 \\
\hline Işık Yansıması & 31 & 33 & 6 & 6 & 38 & 40 & 20 & 21 \\
\hline Işık ve Gölgeler (Bir Tahmin Uygulaması) & 7 & 7 & 33 & 35 & 12 & 13 & 43 & 45 \\
\hline Hacim 4 & 16 & 17 & 12 & 13 & 39 & 41 & 28 & 29 \\
\hline Gündüz Vakti Ay (Öğretilebilir Bir An) & 27 & 28 & 19 & 20 & 34 & 36 & 15 & 16 \\
\hline
\end{tabular}

Not. DÖ: Doğrudan Öğretim, AD: Aktif Doğrudan, YS: Yapılandırılmış Sorgulayıc1, YB: Yapılandırılmamış Buluş.

\footnotetext{
${ }^{4}$ Test maddeleri hakkında daha detaylı bilgiye Güvenç ve Sert (2013)'ün çalışmasından ulaşılabilir.
} 


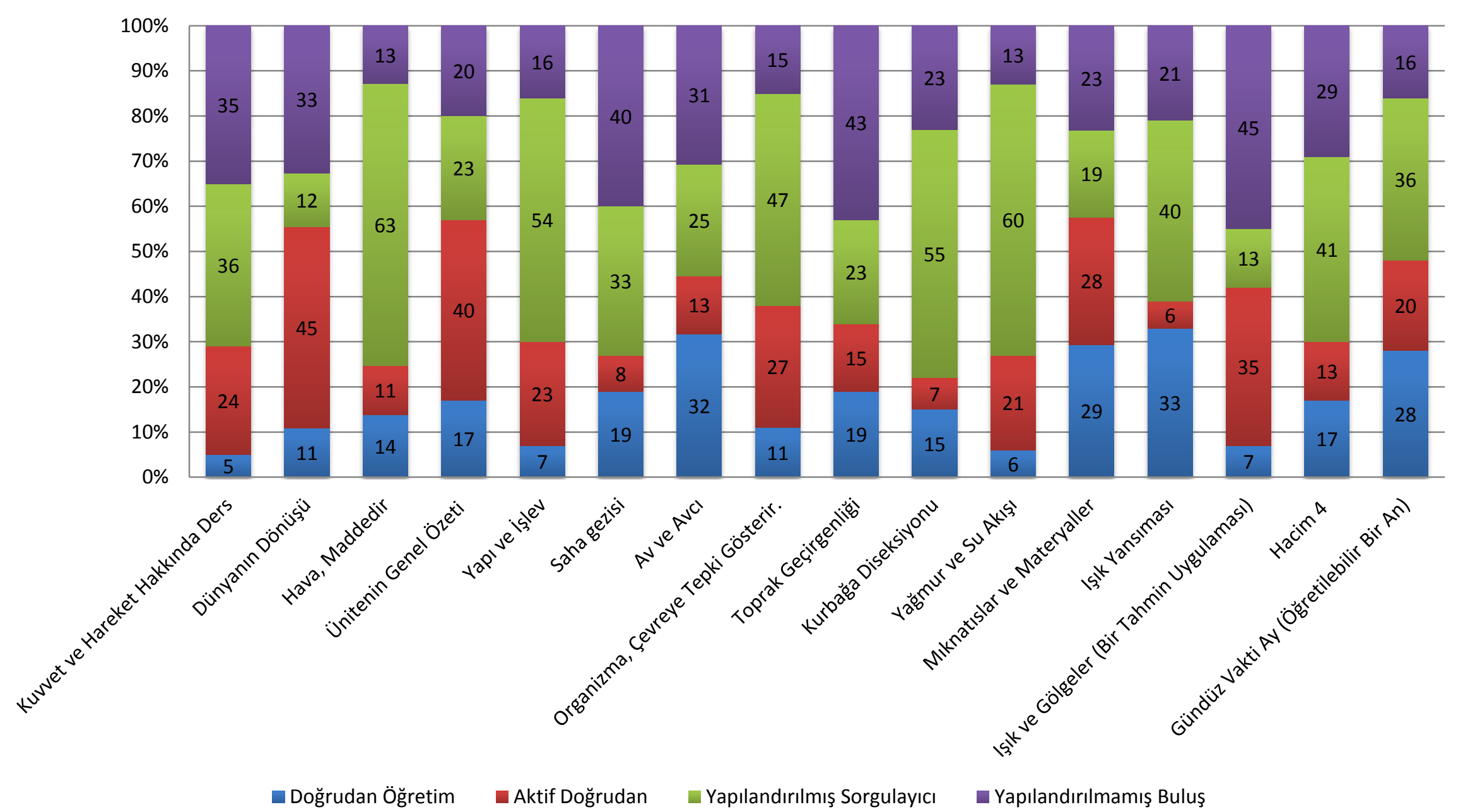

Şekil 3. FÖEYT’nin Her Test Maddesinin Öğretim Yönelimlerine Göre Yüzdelik Dă̆ıllımı 
Dünyanın dönüşü konulu test maddesinde aktif doğrudan yönelimindeki öğretmenler en yüksek yüzdeye sahiptirler. Yani öğretmen önce öğrencilerin ilgisini derse çekmek için ş̧ık ve küreyi kullanarak dünyanın dönmesine yönelik bir uygulama yapmaktadır ve arkasından öğrencilere sorular sormaktadır. Daha sonra konuyu kendisi açıklamakta ve derse girişte yaptığı uygulamayı tekrar ederek öğrenmeyi pekiştirmektedir. Öğretmenlerin yapılandırılmış sorgulayıcı yönelimleri en yüksek hava maddedir konusundadır. Buna göre gazların da maddenin bir hali olduğunu öğrenmeleri için, öğrencilere öğrenecekleri bilgi öğretmen tarafından açıklanmaktadır. Yani öğretmen havanın da maddenin hallerinden biri olduğunu açıkladıktan sonra bu bilginin pekiştirilmesi için vantilatör kullanarak öğrencilerin havayı hissetmeleri için denemeler yapmalarını sağlamaktadır. Işık ve Gölgeler (Bir tahmin uygulaması) konulu test maddesinde yapılandırılmamış buluş yönelimi en yüksektir. Yani öğretmen öğrencilerinin ışı̆̆ın ilerleme yönü ve gölge oluşumu konusunda ön bilgilerinin farkındadır. Işık kaynağı ile cisim arasındaki mesafe değiştikçe gölgenin boyunun nasıl değişeceği hakkında bir problem durumu oluşturulduktan sonra öğrencilerden tahminler yürütmeleri ve tahminlerini kontrol etmeleri için sınıfta denemeler yapmaları istenmektedir. $\mathrm{Bu}$ incelemeden sonra FÖEYT'den her maddesinin betimsel istatistikleri ve Tablo 2'de belirtilen puan aralıklarına göre her test maddesine göre öğretmenlerin fen öğretimi yönelimleri Tablo 4'te sunulmuştur.

Öğretmenlerin aritmetik ortalamalarına göre öğretim yönelimleri Tablo 2'de belirtilen puan aralığına göre genel olarak yapılandırılmış sorgulayıcıdır. Öte yandan test maddelerinin aritmetik ortalamaları ayrı ayrı incelendiğinde, öğretmenler dört maddede $(4,12,13,16)$ aktif doğrudan yönelimini, geriye kalan 12 maddede ise yapılandırılmış sorgulayıcı yönelimini sergiledikleri belirlenmiştir. Yapılandırılmış sorgulayıcı yöneliminde içerik önceden öğretmen ya da ders kitabı tarafından belirlenmekle birlikte, öğrenciler öğretmenin rehberliğinde bir bulguyu ya da düşünceyi keşfetmektedirler (Schuster ve diğ., 2007). Bu durumda öğretmenlerin yönelimlerinin öğrenci merkezli bir öğretim anlayışını yansıttığı söylenebilir. Görüşmeye katılan bütün öğretmenlerin yapılandırılmış sorgulayıcı yöneliminde oldukları maddeler için gerekçelerinde incelendiğinde, öğrenciyi derse başlamadan önce zihinsel olarak aktif hale getirme fikrinin yer aldığı görülmektedir. Örneğin Ö-3 ve Ö-4 kodlu öğretmenler

Konuyu öğrencilerin keşfetmelerini sağlamak daha etkili olur. Çevrelerinde gördükleri olayları böyle öğrenmeleri daha etkili olur (Ö-3).

Tablo 4. FÖEYT'nin Her Maddesinin Betimsel İstatistikleri ve Öğretmenlerin Test Maddelerine Göre Fen Öğretimi Yönelimleri

\begin{tabular}{lllc}
\hline Test maddeleri & Ortalama & $\begin{array}{l}\text { Standart } \\
\text { Sapma }\end{array}$ & $\begin{array}{c}\text { Öğretim } \\
\text { Yönelimi }\end{array}$ \\
\hline 1. Kuvvet ve Hareket Hakkında Ders & & 0,90 & YS \\
2. Dünyanın Dönüşü & 3,00 & 1,05 & YS \\
3. Hava, Maddedir & 2,66 & 0,85 & YS \\
4. Ünitenin Genel Özeti & 2,75 & 1,00 & AD \\
5. Yapı ve İşlev & 2,46 & 0,80 & YS \\
6. Saha gezisi & 2,81 & 1,12 & YS \\
7. Av ve Avcı & 2,94 & 1,23 & YS \\
8. Organizma, Çevreye Tepki Gösterir. & 2,55 & 0,86 & YS \\
9. Toprak Geçirgenliği & 2,66 & 1,16 & YS \\
10. Kurbağa Diseksiyonu & 2,91 & YS \\
11. Yağmur ve Su Akış1 & 2,86 & 0,94 & YS \\
12. Mıknatıslar ve Materyaller & 2,79 & 0,74 & AD \\
13. Işı Yansıması & 2,36 & 1,14 & AD \\
14. Işı ve Gölgeler (Bir Tahmin Uygulaması) & 2,49 & 1,16 & YS \\
15. Hacim 4 & 2,96 & 1,05 & YS \\
16. Gündüz Vakti Ay (Öğretilebilir Bir An) & 2,83 & 1,04 & AD \\
Genel & 2,39 & 1,06 & YS \\
\hline
\end{tabular}


Not. AD: Aktif doğrudan, YS: Yapılandırılmış sorgulayıcı.

Soru sorarak başlamak çocukların düşünmelerini sağlayacak ve sonuca kendilerinin ulaşmasını sağlayacaktır. Tartışma sayesinde çocuklar farklı düşüncelere sahip olacaklardır (Ö-4).

diyerek öğrencinin aktif bir role sahip olduğunu ve bilgiye kendisinin ulaşmasını önermiştir.

Dünya'nın dönüşü konusunun yer aldığı ikinci madde için her ne kadar öğretmenler yapılandırılmış sorgulayıcı yöneliminde olsalar da görüşmeye katılan bütün öğretmenler, öğrencilerin düzeyinin birinci sınıf olması nedeniyle somut materyaller kullanıp, konu hakkında bir açıklama yaptıktan sonra dersin devamında öğrencilere aktif bir rol kazandırmaktadırlar. Örneğin Ö-1 kodlu öğretmenin aşağıda verilen görüşüne göre, öğrenci birinci sınıftaysa düşünmesine yardımcı olmak için diğer sınıf düzeyindeki öğrencilere göre daha fazla desteğe ihtiyaç duyabilir.

Birinci sınıf öğrencileri somut dönemde olduğu için bu konuda biraz daha fazla desteğe ihtiyaç duyacaklardır. Öğretmenin biraz daha fazla destek vermesi gerekiyor.

Tablo 4 daha detaylı incelendiğinde, Ünitenin Genel Özeti, Mıknatıslar ve Materyaller, Işık Yansıması ve Gündüz Vakti Ay (Öğretilebilir Bir An) maddelerinde öğretmenlerin daha öğretmen merkezli bir yaklaşım olan aktif doğrudan yaklaşımını sergiledikleri görülmektedir. Yani öğretmen içeriği doğrudan sunarken ve açıklarken öğrenci öğretmenin önceden açıkladığı bir teorinin doğrulanması işleriyle meşgul olur (Schuster ve diğ., 2007). Öğretmenlere göre bu yönelimlerinin nedeni konunun güçlük düzeyidir. Eğer öğretmen konunun öğrencinin kendi kendine öğrenemeyeceği kadar karmaşık olduğu düşünüyorsa, öğrenciye pasif bir rol vermektedir.

Öğrenciler biraz zor algılayacaklarından dolayı öğretmen açıklama yapar ve öğrenciler kendileri şemayı doldururlar (Ö-1).

Kavramları benim söylemem daha iyi olur. Aksi halde yanlış öğrenme durumları olursa daha kötü olur. O yüzden zor kavramları benim söylemem daha mantıklı (Ö-2).

Fen Bilimleri Öğretmenlerinin Cinsiyetlerine Göre Fen Öğretimine Yönelik Yönelimleri

Fen Bilimleri öğretmenlerinin cinsiyetlerine göre fen öğretimi yönelimlerine ait bulgular Tablo 5'te sunulmuştur. Tablo 5 incelendiğinde, bayan ve erkek öğretmenler arasında bayan öğretmenler lehine anlamlı bir farkın olduğu görülmektedir $(\mathrm{t}=2.022, \mathrm{p}<0.05)$. Bu durum, cinsiyetin fen öğretimine yönelik yönelimi etkilediğini ve bayan öğretmenlerin yönelimlerinin erkek öğretmenlere göre anlamlı düzeyde daha olumlu olduğunu göstermektedir. Bununla birlikte Tablo 2'de verilen aralıklara göre, hem erkek hem de bayan öğretmenlerin yönelimleri yapılandırılmış sorgulayıcı düzeyindedir.

Tablo 5. Fen Bilimleri Öğretmenlerinin Cinsiyetlerine Göre Fen Öğretimi Yönelimleri

\begin{tabular}{cccccc}
\hline Cinsiyet & $\mathrm{N}$ & $\bar{X}$ & $\mathrm{SS}$ & $\mathrm{t}$ & $\mathrm{P}$ \\
& & & & & \\
\hline Bayan & 52 & 44.34 & 4.69 & \multirow{2}{*}{2.022} & .044 \\
Erkek & 43 & 42.30 & 5.06 & & \\
\hline
\end{tabular}

Mesleki Kıdemlerine Göre Fen Bilimleri Öğretmenlerinin Fen Öğretimi Yönelimleri

Mesleki kıdemlerine göre, Fen Bilimleri öğretmenlerinin fen öğretimi yönelimlerine ait betimsel istatistikleri Tablo 6'da sunulmuştur. Fen Bilimleri öğretmenlerinin mesleki kıdemlerine göre fen öğretimi yönelimleri puanlarının aritmetik ortalamaları arasında farklılıkların olduğu görülmektedir. 11-20 yıllık mesleki kıdeme sahip öğretmenler en yüksek aritmetik ortalamaya sahiptir. Bu durumda orta grup olarak isimlendirilebilecek 
öğretmenlerin diğer gruptaki öğretmenlere göre yönelimlerinin daha yapılandırılmış sorgulayıcı olduğu söylenebilir. Bununla birlikte Tablo 2'de verilen aralıklara göre, tüm mesleki kıdem gruplarındaki öğretmenlerin yönelimleri yapılandırılmış sorgulayıcı düzeyindedir.

Tablo 6. Mesleki Kıdemlerine Göre, Fen Bilimleri Öğretmenlerinin Fen Öğretimi Yönelimleri

\begin{tabular}{lccc}
\hline Mesleki Kidem & N & $\bar{X}$ & SS \\
\hline $1-10$ & 46 & 42.11 & 5.25 \\
$11-20$ & 31 & 45.35 & 4.28 \\
20 ve üstü & 18 & 43.44 & 4.30 \\
\hline
\end{tabular}

Mesleki kıdemler arasında gözlenen bu farkın anlamlı olup olmadığı ANOVA ile ve kıdemler arası farkların hangi gruplar arasında olduğunun belirlenmesi ise Tukey testi ile yapılarak sonuçlar Tablo 7'de sunulmuştur. 1-10 yıllık ve 11-20 yıllık kıdeme sahip öğretmenlerin yönelimleri arasında, 11-20 yıllık öğretmenler lehine anlamlı bir farkın olduğu belirlenmiştir $(\mathrm{F}(2-92)=4.263$, $\mathrm{p}<.05)$. Bunun dışında anlamlı fark bulunmamıştır.

Tablo 7. FÖEYT Puanlarının Mesleki Kıdem Gruplarına Göre ANOVA Sonuçları

\begin{tabular}{lcccccc}
\hline $\begin{array}{l}\text { Varyansın } \\
\text { Kaynağ1 }\end{array}$ & $\begin{array}{c}\text { Kareler } \\
\text { Toplamı }\end{array}$ & $\begin{array}{c}\text { Serbestlik } \\
\text { derecesi }\end{array}$ & $\begin{array}{c}\text { Kareler } \\
\text { ortalamas1 }\end{array}$ & F & P & $\begin{array}{c}\text { Anlamlı } \\
\text { Fark }\end{array}$ \\
\hline Gruplar Aras1 & 195.160 & 2 & 97.580 & 4.263 & 0.017 & $1-10$ ve \\
Gruplar içi & 2105.998 & 92 & 22.891 & & & $11-20$ \\
Toplam & 2301.158 & 94 & & & & \\
\hline
\end{tabular}

Görev Yerlerine Göre Fen Bilimleri Öğretmenlerinin Fen Öğretimi Yönelimleri

Fen Bilimleri öğretmenlerinin görev yerlerine göre fen öğretimi yönelimlerine ait bulgular Tablo 8'de sunulmuştur. Tablo 8 incelendiğinde, merkezde görev yapan öğretmenler lehine anlamlı bir farkın olduğu görülmektedir. $\mathrm{Bu}$ durum, öğretmenlerin görev yerinin öğretim yönelimlerini etkileyebileceğini göstermektedir. Tablo 2'de verilen aralıklara göre, merkezde görev yapan öğretmenlerin ilçede görev yapanlara göre öğretim yönelimlerinin daha yapılandırılmış sorgulayıcı olduğu söylenebilir.

Tablo 8. Görev Yerlerine Göre Fen Bilimleri Öğretmenlerinin Fen Öğretimi Yönelimlerinin Mann Whitney U-Testi Sonucu

\begin{tabular}{lccccc}
\hline & N & Sira Ortalaması & Sira Toplamı & U & P \\
\hline Merkez & 39 & 56.41 & 2200.00 & 764.00 & .013 \\
İlçe & 56 & 42.14 & 2360.00 & & \\
\hline
\end{tabular}

$* \mathrm{p}<0.05$

\section{Tartışma ve Sonuç}

$\mathrm{Bu}$ araştırmada, Aydın ilinde görev yapan Fen Bilimleri öğretmenlerinin fen öğretimi yönelimleri belirlenmiş, bu yönelimlerin cinsiyet, mesleki kıdem ve görev yerine göre nasıl değiştiği ortaya çıkarılmıştır. Çalışmanın ilk sonucuna göre, öğretmenlerin fen öğretimi yönelimleri genel olarak yapılandırılmış sorgulayıcıdır. Yani öğrenci, önceden belirlenmiş bilimsel bir içeriği öğrenmek için öğretmenin rehberliğinde bir olguyu ya da bir fikri keşfetmeye çalışmaktadır. Daha anlaşılır hale gelmesi için bu durum şöyle açıklanabilir: Yeni yerler keşfetmek üzere bir araya gelen bir grup kişi tatillerini planlamaktadırlar. Bu amaçla sorumlu bir rehber belirlemiş, rehber de grup üyeleri için hangi yerleri keşfedeceklerini ve bu yerler hakkında neler öğreneceklerini önceden belirlemiştir. Bununla birlikte grup üyeleri bu yerleri rehberin eşliğinde kendileri keşfedecektir. 2004-2005 öğretim yılında yapılan program değişikliğine göre incelendiğinde, öğretmenlerin fen öğretimi yönelimlerinin programda önerilen araştırma vurgusuyla 
benzerlik gösterdiği söylenebilir. Bu durum, programın öğretim anlayışının öğretmenlerin yönelimlerini etkileyebileceğini göstermektedir. Değişik çalışmalar aracılığıyla program değişikliğinin yapıldığı ülkelerde fen öğretmenlerinin öğretim yönelimleri incelenmiştir. Örneğin Nargund-Joshi, Rogers ve Akerson (2011) Hindistan'da öğretmenlerin yönelimlerinin programın öne sürdüğü öğrenci merkezli araştırmaya dayalı öğrenmeye veya k1lavuzlu araştırmaya uygun olduğunu belirlemişlerdir. Türkiye'de ilköğretim öğretmenlerinin öğrenme ve öğretme anlayışlarını inceleyen Baş (2014), öğretmenlerin yapılandırmacı anlayışa sahip olduklarını belirlemiştir. Ancak bu araştırmada Ünitenin Genel Özeti, Mıknatıslar ve Materyaller, Işık Yansıması ve Gündüz Vakti Ay (Öğretilebilir Bir An) maddelerinde öğretmenlerin daha öğretmen merkezli bir yaklaşım olan aktif doğrudan yaklaşımını sergiledikleri görülmektedir (Tablo 4). Bu durum ise şöyle açıklanabilir: yeni yerler keşfetmek üzere bir araya gelen bir grup tatillerini planlamaktadırlar. $\mathrm{Bu}$ amaçla sorumlu bir rehber belirlemişlerdir. Rehber, grup üyeleri için hangi yerleri keşfedeceklerini ve bu yerler hakkında neler öğreneceklerini önceden belirlemiştir. Rehber geziden önce grubun gezilecek yerlerle ilgili öğreneceği bilgileri grup üyelerine açıklamıştır. Grup üyeleri öğrendikleri bilgileri, rehberin eşliğinde gezerek tekrar edeceklerdir. Bu sonuca göre, öğretmenlerin fen öğretimi yönelimlerinin konu alanına göre değişebilmektedir. $O$ halde konu alanı değiştiğinde, öğretmenlerin öğretim yönelimi programda belirtilmiş yönelimden uzaklaşabilmektedir. Benzer şekilde Brown, Friedrichsen ve Abell (2009) ise düzenledikleri öğretmen eğitimi programına katılan öğretmenlerin fen öğretimi yönelimlerinin öğretmen merkezli olduğunu yani öğretimin düz anlatım, öğrenmenin ise dinleme olarak gerçekleştiği düşüncesine sahip olduklarını ortaya çıkarmışlardır. Önceki yıllarda yapılan bir başka çalışma ise öğretmenlerin araştırmaya dayalı öğrenme yaklaşımının önemini kabul ettiklerini ancak okuldaki geleneksel ögretim yaşantılarıyla araştırmaya dayalı öğrenmeyi bağdaştırmakta zorlandıklarını göstermiştir (Zhang ve diğ., 2003). Türkiye'de program değişikliğinden sonra yapılan önceki çalışmalarda da benzer şekilde, programın araştırmaya dayalı öğrenme vurgusuyla öğretmenlerin öğretim bilgileri arasında uyumsuzluğun olduğunu gösteren sonuçlar elde edilmiştir. Örneğin öğretmenlerin geleneksel yöntemleri, alternatif değerlendirme yöntem ve tekniklerine göre daha fazla kullandıkları (Güneş, Şener, Hoplan, Çelikoğlu ve Demir, 2010), öğrenci merkezli öğretim yöntemlerinin önemini kabul etmelerine rağmen, bu yöntemleri bilmedikleri (Işıkoğlu, Baştürk ve Karaca, 2009) veya öğrencileri öğrenme sürecine aktif olarak dâhil eden ve bilimsel araştırma becerilerini geliştirmede yardımcı olan uygulamaları tercih etmedikleri belirlenmiştir (Şimşek, Hırça ve Coşkun, 2012). Öğretmenler program değişikliğine iyi niyetli yaklaşsalar da, bu değişikliğin özünü oluşturan yöntemler hakkında yeterince bilgi sahibi olamadıklarında, programı var olan koşullara göre biçimlendirilebilmektedirler. O halde Türkiye'deki program değişikliğinin öğretmenlere 5E öğrenme modeli aracılığıyla iletildiği dikkate alındığında bu biçimlendirmenin nasıl gerçekleştirildiği daha anlaşılır olmaktadır. Öğretmenlerin bu modele yönelik bilgileri incelendiğinde, öğretmenlerin girme, açıklama ve değerlendirme aşamalarında programla uyumlu görüşlere sahip oldukları ancak keşfetme, derinleştirme aşamalarında ise yapılandırmacı yaklaşımın öngördüğü etkinlikler gerçekleştirmede sıkıntılar yaşadıkları belirlenmiştir (Ayvacı ve Bakırcı, 2012). Bir başka çalışmada ise keşfetme ve açıklama aşamasında öğrencilerin ön bilgileriyle ilgili denemeler yaparak yeni öğrenecekleri kavramı keşfedecekleri, ön bilgilerinde hatalar varsa bu hataları fark edecekleri ve yeni bilgiyi kendilerinin oluşturacakları öğrenme etkinlikleri hakkında öğretmenlerin yanlış bilgilere sahip oldukları belirlenmiştir (Yıldız Feyzioğlu ve Demirci, 2013). Sonuç olarak, programın öne sürdüğü öğrenci merkezli öğretim anlayışıyla öğretmenlerin araştırmaya dayalı öğrenmeye yönelik görüşleri uyumlu görünse de, belirgin bir öğretim yöntemi açısından incelendiğinde bu görüşlerin programın anlayışından uzaklaştığı söylenebilir.

Çalışmanın ikinci sonucuna göre bayan öğretmenlerin fen öğretimi anlayışlarının erkek öğretmenlere göre anlamlı düzeyde daha yapılandırılmış sorgulayıcıdır. Değişik araştırmaların sonuçları da cinsiyetin öğretmenlerin fen öğretimine yönelik görüşlerini etkileyen bir değişken olduğunu göstermiştir. Örneğin Marshall, Horton, Igo ve Switzer (2008)'in çalışmasına göre, bayan öğretmenler erkek öğretmenlere göre araştırmaya dayalı öğrenmeye daha fazla zaman ayırdıklarını belirtmişlerdir. Supovitz ve Turner (2000) ise çalışmalarında araştırmaya dayalı etkinliklerde erkek öğretmenlerin bayan öğretmenlere göre daha 
geleneksel sınıf kültürüne sahip olduklarını ortaya çıkarmışlardır. Nelson-Laird ve diğ. (2007) de benzer şekilde bayan öğretmenlerin erkek öğretmenlere göre öğrencilerin aktif biçimde öğrenebildikleri sınıf etkinliklerine daha fazla yer verdiklerini belirlemiştir. Bu durum, toplumun öğretmenlik mesleğine cinsiyet açısından nasıl bir anlam yüklediğiyle ilişkilendirilmektedir. Değişik araştırmacılar, toplumda bayanların daha destekleyici davranışlar sergileyeceği (Cushman, 2005) görüşünden yola çıkarak öğretmenlik mesleğinin daha çok bayanlara özgü bir meslekmiş gibi algılandığını (Hussain, Ali, Khan, Ramzan ve Qadeer 2011) ve bayan öğretmenlerin mesleklerini yapmaktan daha fazla keyif alıyor olabileceklerini belirtmektedirler (Hean ve Garrett, 2001). Bu durum, cinsiyetin öğretmenlerin fen öğretimi uygulamalarını etkileyen bir unsur olduğunu yeniden ortaya çıkarmaktadır.

Çalışmanın üçüncü sonucuna göre Fen Bilimleri öğretmenlerinin fen öğretimi yönelimleri arasında, 1-10 yıllık ve 11-20 yıllık kıdeme sahip öğretmenlerin tutumları arasında, 11-20 yıllık öğretmenler lehine anlamlı bir fark vardır. Işı1koğlu ve diğ., (2009)'nin çalışmasında da benzer şekilde, mesleki kıdemleri açısından orta grup olarak isimlendirilecek 9-16 yıllık öğretmenlerin öğrenci merkezli eğitime yönelik inançlarının diğer gruplardan daha yüksek olduğu belirlenmiştir. Aslında mesleğinde yeni sayılabilecek Fen Bilimleri öğretmenlerinin fen öğretimi yönelimlerinin daha yapılandırmacı olması beklenirken, daha kıdemli öğretmenlerin puanları daha yüksektir. Öğretmenlerin, öğretmenlik mesleklerinin ilk yıllarında öğrencilerinin davranışlarını yönetirken, öğrencileri derse güdülerken ve öğretilecek konunun içeriğine karar verirken zorlandıkları belirtilmektedir (Joerger, 2002). Bu durumda öğretmenler sahip oldukları öğretim bilgilerini sınıf uygulamalarında doğrudan kullanamadıklarından bir çatışma yaşıyor olabilirler (Luft, Dubois, Nixon ve Campbell, 2015). Ancak öğretmenler öğretimde yeni yaşantılar geçirdikçe, bu çatışmay1 çözmek için kendilerine göre çözümler üretebilir hale geldiklerinden, öğretim yönelimleri mesleki kıdemleri arttıkça daha yapılandırmacı yönde değişmiş olabilir. Örneğin bir çalışmanın sonucuna göre, öğretmen adayları sahip oldukları konu alanı bilgisini öğrenciler için anlaşılır hale getirmek için çaba harcarken, bu adaylar öğretmen olduklarında öğrencilerle geçirdikleri etkileşimler arttıç̧a, öğretimde yapılandırmacı anlayışı yansıtan tekniklere daha fazla yer vermişlerdir (Findlay ve Bryce, 2012). Öğretmenler bu teknikleri daha fazla kullanıp öğretim bilgilerini ilerlettikçe, henüz öğretmedikleri veya yabancı oldukları konuları daha kolay öğretebilir hale gelmektedirler (Sanders, Borko ve Lockard, 1993). Öğretmenlerin geçirdikleri yaşantılarla beraber öğretim yönelimlerinde yapılandırmacı yaklaşıma doğru bir geçiş olsa da göreve yeni başlayan öğretmenlerin öğretim yönelimlerini değiştirmeye daha hazır oldukları Luft ve Zhang (2014) gözden kaçırılmamalıdır. Çalışmanın dördüncü sonucuna göre Fen Bilimleri öğretmenlerinin fen öğretimine yönelik yönelimleri görev yerlerine göre karşılaştırıldı̆̆ında, merkezde görev yapan öğretmenlerin yönelimlerinin ilçelerde görev yapan öğretmenlere göre daha yüksek olduğu belirlenmiştir. Diğer araştırmalar da benzer şekilde şehir merkezine daha yakın yerde görev yapan öğretmenlerin kılavuzlu araştırma yönelimini buna karşın ilçelerde görev yapan öğretmenlerin aktif doğrudan yönelimini sergilediklerini belirlemiştir (Ramnarain, 2014; Ramnarain ve Schuster, 2014). Görev yerlerinde gözlenen bu durum öğretmenlerin içinde bulundukları fiziksel koşullarla ilişkilendirilirken, mevcut kaynakların yetersizliği, sınıf mevcutlarının kalabalık olması ve öğretmenlerin öğretim bilgilerindeki eksikleri nedeniyle öğretmen merkezli öğretime yönelebilmektedirler (Ramnarain, 2014). Cheung (2009)'a göre, program üzerinde yapılan makro değişikliklerin amacı eğitimsel amaçların yenilenerek farklı bir eğitim sisteminin yerleştirilmesiyken, mikro düzeyde farklı yerlerde öğrenim gören öğrenciler için eğitimin kalitesinin ve eğitim standartlarının eşit hale getirilmesi amaçlanmalıdır. Mikro ve makro değişiklikler arasında bir dengesizlik oluştuğunda yani öğretmenler belirtilen fiziksel koşullar nedeniyle program değişikliğini içselleştiremediklerinde daha öğretmen merkezli bir öğretime yönelimini tercih ettikleri ortaya çıkmaktadır.

\section{Öneriler}

Çalışmada elde edilen sonuçlardan öğretmenlerin genel olarak yapılandırılmış sorgulayıcı yaklaşımı benimsedikleri; cinsiyetin, mesleki kıdemin ve görev yaptıkları bölgenin öğretim yönelimleri üzerinde etkili 
olduğu söylenebilir. Ancak elde edilen sonuçlar bu çalışmanın örneklemi ile sınırlıdır. Farklı bölgelerdeki öğretmenlerin de öğretim yaklaşımları belirlenerek bölgeler arası karşılaştırma yapılabilir.

Öğretmenlerin diğer yönelimlere göre neden daha çok yapılandırılmış sorgulayıcı yönelimi benimsedikleri, belirttikleri yönelim ile sınıflarında uyguladıkları yönelim karşılaştırılarak incelenebilir. Öğretmenlerin derse hazırlık, öğretim ve değerlendirme süreçleri izlenerek sahip oldukları yönelimin her bir süreci nasıl belirlediği araştırılabilir. Böylece yönelime göre her bir sürecin karakteristik özellikleri belirlenebilir. Ayrıca öğretmenlerin pedagojik alan bilgilerindeki yeterlilik ile öğretim yönelimleri arasındaki ilişki derinlemesine araştırma süreçleri incelenebilir.

$\mathrm{Bu}$ çalışmayla öğretmenlerin görev yaptıkları bölgenin öğretim yönelimi üzerine etkili olduğu belirlenmiştir. Alan yazında da okul kültürünün öğretim yönelimleri üzerinde etkili olduğu belirtilmişti. Bu sonuçlardan yola çıkarak okul ortamında yer alan diğer öğretmenlerin ve idarecilerin yaklaşımının, okulun fiziki koşullarının, öğrencilerin hazır bulunuşluklarının, ders programının öğretim yönelimi üzerine etkisi sürece dayanan araştırma teknikleri ile incelenebilir.

\section{Kaynaklar}

Akçil, M. ve Oğuz, A. (2015). Fen bilgisi öğretmenlerinin öz yeterlik inancı ile öğrenen özerkliğini destekleme davranışları arasındaki ilişkinin incelenmesi. Turkish Studies, 10(11), 1-6.

Akıncı, B. ,Uzun, N. ve Kışoğlu, M. (2015). The problems experienced by science teachers in their professional difficulties they are confronted with in science teaching. International Journal of Human Sciences, 12(1), 1189-1215.

Akpınar, E., Yıldız, E., Tatar, N., ve Ergin, Ö. (2009). Students' attitudes toward science and technology: an investigation of gender, grade level, and academic achievement. Procedia Social and Behavioral Sciences, 1, 2804-2808.

Aksit, N. \& Sands, M. (2006). Issues and Challenges Facing Education in Turkey. In Earnest, J. ve Treagust, D. (Eds.), Education reform in societies in transition: International perspectives. Sense Publishers: The Netherlands.

Altun, E. H., Feyzioğlu, B. ve Demirdağ, B. (2011). Liseler için yapılandırmacı ögrenme etkinlikleri ile zenginleştirilmiş etkileşimli sanal kimya laboratuvarı geliştirilmesi, $108 \mathrm{~K} 293$ nolu TÜBİTAK Projesi Sonuç Raporu.

Anderson, C. W., \& Smith, E. L. (1987). Teaching science. In V. Richardson-Koehler (Ed.), Educators' handbook: a research perspective (pp. 84-111). New York: Longman.

Aydın, Ö., Tunca, N. ve Şahin, S.A. (2015). Fen bilgisi öğretmen adaylarının öğretme ve öğrenme anlayışlarının çeşitli değişkenler açısından incelenmesi. Kastamonu Eğitim Fakültesi Dergisi, 23(3), 1331-1346.

Ayvacı, H.Ş. ve Bakırc1, H. (2012). Fen ve teknoloji öğretmenlerinin fen öğretim süreçleriyle ilgili görüşlerinin 5E modeli açısından incelenmesi. Türk Fen Eğitim Dergisi, 9(2), 132-151.

Baş, G. (2014). İlköğretim öğretmenlerinin öğretme-öğrenme anlayışlarının bazı değişkenler açısından değerlendirilmesi. Dicle Üniversitesi, Ziya Gökalp Eğitim Fakültesi Dergisi, 22(Ocak), 18-30.

Billings, L. R. (2001). Assessment of the learning cycle and inquiry based learning in high school physics education. Unpublished master's thesis, Michigan State University. 
Brown P., Friedrichsen P. \& Abell S. K., (2009). Do beliefs change? Investigating prospective teachers' science teaching orientations during an accelerated post-baccalaureate program. In Taşar, M.F. ve Çakmakçı, G. (2009). Contemporary science educatıon research: teachıng, The European Science Education Research Association (ESERA) Conference, August 31-September 4, 2009 (pp. 41-51), Istanbul, Turkey.

Brown, P. (2008). Investigating teacher knowledge of learners and learning and sequence of science instruction in an alternative certification program. Unpublished doctoral dissertation, University of Missouri, Columbia.

Cheng, Y. C. (2009). Hong Kong educational reforms in the last decade: Reform syndrome and new developments. International Journal of Educational Management, 23 (1), 65-86.

Cheung, D. (2007). Confirmatory factor analysis of the attitude toward chemistry lessons scale. Proceeding of the 2nd NICE Symposium, 30-31 July 2007 (00029), Taipei, Taiwan.

Cheung, D. (2009). Students' attitudes toward chemistry lessons: The interaction effect between grade level and gender. Journal of Research in Science Teaching, 39(1), 75-91.

Cobern, W. W.,Schuster, D., Adams, B., Skjold, B. A., Mugaloglu, E. Z., Bentz, A., \& Sparks, K. (2014). Pedagogy of science teaching test: Formative assessments of science teaching orientations. International Journal of Science Education, 36 (13), 2265-2288.

Cohen, L., Manion, L. \& Morrison, (2000). Research methods in education (5th Ed.). London: Routledge Falmer.

Cushman, P. (2005). It's just not a real bloke's job: male teachers in the primary school. Asia-Pacific Journal of Teacher Education, 33(3), 321-338.

Çakır, N.K., Şenler, B., ve Taşkın, B.G. (2007). İlköğretim II. kademe öğrencilerinin fen bilgisi dersine yönelik tutumlarının belirlenmesi. Türk Ĕgitim Bilimleri Dergisi, 5 (4), 637-655.

Donovan, M. S., \& Bransford, J. D. (Eds.). (2005). How students learn: History, mathematics, and science in the classroom. Washington, DC: National Academy Press.

Elmas, R., Demirdöğen, B. ve Geban, Ö. (2011). Kimya öğretmen adaylarının gelecekte sınıflarındaki fen öğretimiyle ilgili çizimleri. Hacettepe Üniversitesi Eğitim Fakültesi Dergisi, 40, 164-175.

Findlay, M., \& Bryce, T. G. K. (2012). From teaching physics to teaching children: Beginning teachers learning from pupils. International Journal of Science Education, 34, 2727-2750.

Friedrichsen, P. (2002). A substantive-level theory of highly-regarded secondary biology teachers' science teaching orientations. Unpublished doctoral dissertation. The Pennsylvania State University, University Park.

Friedrichsen, P., \& Dana, T. (2005). A substantive-level theory of highly-regarded secondary biology teachers' science teaching orientations. Journal of Research in Science Teaching, 42, 218 -244.

Grossman, P. L. (1990). Making of a teacher: teacher knowledge and teacher education. New York: Teachers College Press. 
Güneş, T., Şener, D.N., Hoplan, M., Çelikoğlu, M. ve Demir, E.S. (2010). Öğretmenlerin alternatif değerlendirme konusundaki görüşleri ve yaptıkları uygulamalar, International Conference on New Trends in Education and Their Implications, 11-13 November 2010, Antalya, Turkey.

Gür, B.S., Çelik, Z. ve Özoğlu, M. (2012). Policy options for Turkey: A critique of the Interpretation and utilization of PISA results in Turkey. Journal of Education Policy, 27(1), 1-21.

Güvenç H. ve Sert G. (2013). Fen öğretimi eğitsel yaklaşım testi Türkçe uyarlama çalışması, 22. Ulusal Eğitim Bilimleri Kurultayı, 5-7 Eylül 2013, (pp.1-1), Eskişehir, Türkiye.

Hean, S. \& Garrett, R. (2001). Sources of job satisfaction in science secondary school teachers in Chile. Compare, 31: 363-379.

Hoy, W.K., \& Woolfolk, A.E. (1989). Supervising student teachers. In A. Woolfolk (Ed.), Research perspectives on the graduate preparation of teachers (pp. 108-131). Englewood Cliffs, NJ: PrenticeHall.

Hussain, S., Ali, R., Khan, M. S., Ramzan, M., \& Qadeer, M. Z. (2011). Attitude of secondary school teachers towards teaching profession. International Journal of Academic Research, 3(1), 985-990.

Inozu, J. (2011). Developing learner autonomy in the language class in Turkey: voices from the classroom. Asia Pacific Education Review, 12: 523-531.

Isikoglu, N.,Basturk, R., ve Karaca, F. (2009). Assessing in-service teachers' instructional beliefs about student-centered education: A Turkish perspective. Teaching and Teacher Education, 25(2), 350356.

Işıkoğlu, N., Baştürk, R., ve Karaca, F. (2010). İlköğretim öğretmenlerine yönelik yapılandırmacı interaktif hizmet içi eğitim programı (YİHEP). 104K024 No'lu Tübitak Projesi Sonuç Raporu.

Joerger, R. M. (2002). A comparison of the in service education needs of two cohorts of beginning Minnesota agricultural education teachers. Journal of Agricultural Education, 43(3), 11-24.

Karamustafaoğlu, O. (2004) Fen ve teknoloji öğretmenlerinin öğretim materyallerini kullanma düzeyleri: Amasya ili örneği. AÜ. Bayburt Ĕ̈itim Fakültesi Dergisi, 1(1), 90-101.

Karamustafaoğlu, O., Bayar, A. ve Kaya, M. (2014). Fen bilimleri öğretmenlerinin kullandıkları öğretim yöntem ve teknikleri üzerine bir araştırma: Amasya örneği. Kuramsal Eğitimbilim Dergisi, 7(4), 436462.

Karamustafaoğlu, S., Salar, U. ve Celep, A. (2015). Ortaokul 5. sınıf fen bilimleri ders kitabına yönelik öğretmen görüşleri. Gazi Eğitim Bilimleri Dergisi, 1(2), 93-117.

Kavak, N., Tufan, Y. ve Demirelli, H. (2006). Fen-teknoloji okuryazarlığı ve informal fen eğitimi: gazetelerin potansiyel rolü. Gazi Üniversitesi Eğitim Fakültesi Dergisi, 26 (3), 17-28.

Kılıç, G.B, Haymana, F. ve Bozyılmaz, B. (2008). İlköğretim fen ve teknoloji dersi öğretim programı'nın bilim okuryazarlı̆̆ 1 ve bilimsel süreç becerileri açısından incelenmesi. Eğitim ve Bilim, 33(150), 5263.

Kılıç, G.B. (2002). Dünyada ve Türkiye'de fen öğretimi, V. Ulusal Fen Bilimleri ve Matematik Eğitimi Kongresi,16-18 Eylül 2002, Ankara. 
Koballa, T.R., Glynn, S.M., Upson, L., \& Coleman, D.C. (2005). Conceptions of teaching science held by novice teachers in an alternative certification program. Journal of Science Teacher Education, 16, 287-308.

Krishnaswamy, O.R. \& Ranganathan, M. (2010). Methodology of research in social science. Bombay: Himalaya Publication.

Lakin, J. \& Wallace, C. (2015). Assessing dimensions of inquiry practice by middle school science teachers engaged in Professional development program. Journal of Science Teacher Education, 26(2), 139162.

Lakin, J. M., \& Wallace, C. S. (2015). Assessing dimensions of inquiry practice by middle school science teachers engaged in a professional development program. Journal of Science Teacher Education, 26(2), 139-162.

Lotter, C., Harwood, W. S., \& Bonner, J. J. (2007). The influence of core teaching conceptions on teachers ${ }^{\text {ee }}$ use of inquiry teaching practices. Journal of Research in Science Teaching, 44, 1318-1347.

Luft, J. A.,Dubois, S. L., Nixon, R. S., \& Campbell, B. K. (2015). Supporting newly hired teachers of science: Attaining teacher Professional standards. Studies in Science Education, 51 (1), 1-48.

Luft, J.A. \& Zhang, C. (2014). The Pedagogical Content Knowledge and beliefs of newly hired secondary science teachers: The first three years. Education Quimica, 25(3), 325-331.

Magnusson, S.,Krajcik, J., \& Borko, H. (1999). Nature, sources and development of pedagogical content knowledge for science teaching. In J. Gess-Newsomeve N. G. Lederman (Eds.), Examining pedagogical content knowledge: the construct and its implications for science education (pp. 95132). Dordrecht: Kluwer.

Marshall, J., Horton, J., Igo, B., \& Switzer, D. (2009). K-12 science and mathematics teachers' beliefs about and use of inquiry in the classroom. International Journal of Science and Mathematics Education, 7, 575-596.

Milli Eğitim Bakanlığı, Talim Terbiye Kurulu Başkanlığı. (2008). Fen ve teknoloji öğretmeni özel alan yeterlikleri. Ankara: Devlet Kitapları Müdürlüğü.

Milli Eğitim Bakanlığı. (2005). İlkögrretim Fen ve Teknoloji Dersi (6, 7 ve 8. sınıflar) öğretim programı ve kılavuzu. Ankara: Devlet Kitapları Müdürlüğü.

Milli Eğitim Bakanlığı. (2013). Fen Bilimleri Dersi (3,4,5,6, 7 ve 8. sınıflar) öğretim programı ve kılavuzu. Ankara: Devlet Kitapları Müdürlüğü.

Nargund-Joshi, V. Park Rogers, M.A., \& Akerson, V.L. (2011). Exploring Indian secondary teachers' orientations and practice for teaching science with respect to reform. Journal of Research in Science Teaching, 48(6), 624-647.

Nargund-Joshi, V. Park Rogers, M.A., \& Akerson, V.L. (2011). Exploring Indian secondary teachers' orientations and practice for teaching science with respect to reform. Journal of Research in Science Teaching, 48(6), 624-647.

National Research Council. (2011). National science education standards. Washington, DC: National Research Council. 
Nelson Laird, T.F.,Garver, A., Niskode', A.S. \& Chang, L. (2007). Gender gaps: Understanding teaching style differences between men and women, June 2-6, 2007 (56-64), Annual Meeting of the Association for Institutional Research, Kansas City, MO.

Ramnarain, U. \& Schuster, D. (2014). The Pedagogical Orientations of South African physical sciences teachers towards inquiry or direct instructional approaches. Research in Science Education, 44(4), 627-650.

Ramnarain, U. D. (2014). Teachers' perceptions of inquiry-based learning in urban, suburban, town ship and rural high schools: the context-specificity of science curriculum implementation in South Africa. Teaching and Teacher Education, 38, 65-75.

Ramnarain, U., Nampota, D. \& Schuster, D. (2016). The spectrum of pedagogical orientations of malawian and south african physical science teachers towards inquiry. African Journal of Research in Mathematics, Science and Technology Education, DOI: 10.1080/10288457.2016.1162467.

Samuelowicz, K., \& Bain, J. D. (2001). Revisiting academics ${ }^{e e}$ beliefs about teaching and learning. Higher Education, 41, 299-325.

Sanders, L. R., Borko, H., \& Lockard, J. D. (1993). Secondary science teachers' knowledge base when teaching science courses in and out of their area of certification. Journal of Research in Science Teaching, 30(7), 723-736.

Schuster, D.,Cobern, W.W., Applegate, B., Schwartz, R., Vellom, P., \& Undreiu, A. (2007). Assessing pedagogical content knowledge of inquiry science teaching-Developing an assessment instrument to support the undergraduate preparation of elementary teachers to teach science as inquiry. October 19-21, 2007, Proceedings of the National STEM Conference on Assessment of Student Achievement, hosted by the National Science Foundation and Drury University, Washington D.C.

Shulman, L.S. (1986). Those who understand: Knowledge growth in teaching. Educational Researcher, 15(2), 4-14.

Supovitz, J. A., \& Turner, H. M. (2000). The effects of Professional development on science teaching practices and classroom culture. Journal of Research in Science Teaching, 37(2), 963-980.

Şahin, M. (2015). Öğretim materyallerinin öğrenme-öğretme sürecindeki işlevine ilişkin öğretmen görüşlerinin analizi. K. Ü. Kastamonu Eğitim Dergisi, 23(3), 995-1012.

Şimşek, H., Hırça, N. ve Coşkun, S. (2012). İlköğretim Fen ve Teknoloji Öğretmenlerinin öğretim yöntem ve tekniklerini tercih ve uygulama düzeyleri: Şanlıurfa ili örneği. Mustafa Kemal Üniversitesi Sosyal Bilimler Enstitüsü Dergisi. (9) 18, 249-268.

Tabak, R. (2007). Illköğretim 5. sinıf fen ve teknoloji ders programının öğrenme öğretme ve ölçme değerlendirme yaklaşımları kapsamında incelenmesi (Muğla ili örneği). Yayınlanmamış yüksek lisans tezi, Muğla Üniversitesi, Sosyal Bilimler Enstitüsü, Muğla.

Thomas, J.A., Pedersen, J.E., \& Finson, K.D. (2001). Validating the Draw- A-Science-Teacher-Test Checklist (DASTT-C): Exploring mental models and teacher beliefs. Journal of Science Teacher Education, 12(3), 295-310.

Tseng, C.H., H.L. \& Chin, C.C. (2013). How to help teachers develop inquiry teaching: Perspectives from experienced science teachers. Research in Science Education, 43(2), 809-825. 
Ünal, G., ve Akpinar, E. (2006). To what extent science teachers are constructivist in their classrooms. Journal of Baltic Science Education, 2 (10), 40-50.

Van Driel, J.H., Beijaard, D. \& Verloop, N. (2001). Professional development and reform in science education: The role of teachers' practical knowledge. Journal of Research in Science Teaching, $38(2), 137-158$

Whyte, A., \& Ellis, N. (2003). Graphic representation as a bridge to understanding conceptual teaching. Arts and Learning Research Journal, 19 (1), 167- 194.

Wongsopawiro, D. (2012). Examining science teachers' pedagogical content knowledge in the context of a professional development program. Unpublished doctoral dissertation, Leiden University, The Netherlands.Ağgül-Yalçın, F. (2011). Investigation of science teacher candidates' self-efficacy beliefs of science teaching with respect to some variables. International Online Journal of Educational Sciences, 3(3), 1046-1063.

Yapıc1, M. ve Leblebiciler, N.H., (2007). Öğretmenlerin yeni ilköğretim programına ilişkin görüşleri. Ilköğretim Online Dergisi, 6(3), 480-490.

Yıldırım, A. ve Şimşek, H. (2008). Nitel Araştırma Yöntemleri. (7. Baskı). Ankara: Seçkin Yayıncılık.

Yıldız-Feyzioğlu, E. ve Demirci, N. (2013). Sınıf ve fen bilimleri öğretmenlerinin 5E öğrenme modeliyle ilgili farkındalıkları. Mustafa Kemal Üniversitesi Eğitim Fakültesi Dergisi, 10 (24), 131-163.

Zhang, B., Krajcik, J., Wang, L., Hu, J., Wu, J., Qiang, Y., et al. (2003). Opportunities and challenges of China's inquiry-based education reform in middle and high school: Perspectives of science teacher sand teacher educators, August 21-25, 2003 (1-40), The American Educational Research Association Annual Meeting, Chicago, April.

\section{Extended Abstract}

Purpose

The pedagogical orientations of teachers play an important role in reaching the goals set forth in the Science Program. Although the Program was revised in 2013, there are as yet not enough studies evaluating teachers' orientations to ensure the achievement of the goals of the program. Identifying the pedagogical orientations of teachers in the light of the revised program will provide knowledge regarding the extent to which the program has been implemented in the schools and how competent teachers are in the implementation. The purpose of this research is to identify the science teaching orientations of teachers of Science, and to determine how orientations change according to gender, professional seniority and school location. The research questions were determined to be:

1. What are the science teaching orientations of Science teachers?

2. Are there significant differences between science teaching orientations and the Science teacher's gender?

3. Are there significant differences between science teaching orientations and the Science teacher's professional seniority?

4. Are there significant differences between science teaching orientations and the Science teacher's school location? 


\section{Method}

The research aims to identify the science teaching orientations of Science teachers. Since an attempt is being made to describe the existing status of teachers, the study was carried out using a survey model.

The study group in the research comprised Science teachers working in the city center and in the districts of the province of Aydin. The convenience sampling method was used in the sample selection. Ninety-five teachers working in the same city that could be reached or conveniently contacted were recruited into the study. To identify the reasons for the pedagogical orientations the teachers favored, four teachers chosen from the study group were invited to participate in semi-structured interviews. These teachers were coded as $\mathrm{T} 1, \mathrm{~T} 2, \mathrm{~T} 3$, and T4. In the selection of these teachers, the teaching orientations that had emerged in the research were taken into consideration and teachers who had marked choices that conformed with these orientations were interviewed.

The Pedagogy of Science Teaching Test (POSTT) was employed to identify the teachers' science teaching orientations. This test contains 16 items. Each item offers the teachers four choices. The choices represent the four different basic pedagogical orientations of didactic direct, active direct, guided inquiry and open inquiry. After marking each item on the POSTT, the teachers in the study were asked the reason for their choice. This way, an effort was made to understand how the teachers' teaching orientations changed according to different factors. The results of the independent test with which the mean scores of the participants in the lower and upper (27\%) groups were compared showed that the difference between mean scores was significant in all items.

Since the choices given for each item in the POSTT represented the four different orientations of didactic direct, active direct, guided inquiry and open inquiry, these orientations were assigned the scores of 1, 2, 3 and 4, respectively, and the descriptive statistics of mean and standard deviation were calculated for each item of the test. To establish a relationship between the means obtained and the teaching orientations, interval widths were calculated for each orientation.

Results

When the responses to the test are reviewed, it is seen that the teachers' orientations change according to the course subject. When the topic "Reflection of Light" is studied, it can be seen that the most popular approach is didactic direct. In this, the teacher starts off the lesson by explaining a scientific law, then draws a diagram or gives an example to make the law more comprehensible. Although the example provided demonstrates a particular application, it is a verification of the law the students have learned. In the test item on the revolution of the earth, the highest number of teachers exhibited an active direct orientation. In this orientation, the teacher first uses a source of light and a globe to draw the students' attention to the lesson, actively demonstrating how the earth revolves and then asks students questions. Later, the teacher explains the subject and reinforces the learning by repeating the demonstration that was introduced at the start of the lesson. The guided inquiry orientation of the teachers was highest in the subject of "air is matter." In this, the teacher explains the materials the students must learn to teach them that gas is also a state of matter. This means that after explaining that air is a state of matter, to reinforce this knowledge, the teacher uses an electric fan to conduct some experiments in which the students can feel the air. The open inquiry orientation can be seen to be highest in the test item covering Light and Shadows (An Estimation Application). Here, the teacher is aware of the students' knowledge about the direction light travels and the formation of shadows. After posing a problem on how the length of a shadow changes as the distance between the source of light and an object changes, the teacher asks the students to make some estimates and then check their results by experimenting in the classroom. 
The pedagogical orientations of the teachers were generally of the guided inquiry type. The following example may help to elaborate on this: A group of people comes together to plan a vacation where they will explore new locations. A guide has been assigned to them for this purpose and this guide has determined beforehand which places the group will explore and what they will learn at the different locations. At the same time, the members of the group will be exploring the various locations while accompanied by a guide. In this case, it may be said that the teachers' orientations reflect a student-centered pedagogical understanding. In examining the reasons the teachers gave for their guided inquiry orientation in the items, it can be seen that the teachers base this preference on wanting the student to be mentally active before coming to class. For example, according to the teachers coded T-3 and T-4:

Having the students explore the subject themselves is more effective. Learning about the phenomena around them in this way is more effective (T-3).

Starting off by asking questions makes the students think and allows them to reach the conclusion themselves. A discussion will cause them to have different ideas (T-4).

Thus, the teachers have recommended that students have an active role in learning and reach the knowledge by themselves. In item on Light and Shadows (An Estimation Application), to give students the chance to assess themselves, they are asked to make estimations and to carry out experiments to verify their estimations. Because of this, it is seen that the student again comes to class actively. Although the teachers exhibited a guided inquiry orientation in item 2 about the revolution of the earth, because the students were in the first grade, the teachers chose to give the students an active role after first offering them an explanation about the subject using concrete materials. According to what T-1 said, given below, a first-level student may need more support compared to students at higher levels to help him/her in the process of thinking.

Since first-grade students are in the concrete stage of their development, they will need more support with this material. The teacher has to offer more help.

It is seen that the teachers preferred a more teacher-centered approach, the active direct orientation, in the items on the Unit General Summary, magnets and materials, reflection of light (A Teachable Moment). This can be explained in this way: A group of people comes together to plan a vacation where they will explore new locations. A guide has been assigned to them for this purpose. This guide has determined beforehand which places the group will explore and what they will learn at the different locations. Prior to the trip, the guide explains to them the information they will be learning about the places they visit. The members of the group will review what they have learned when they travel accompanied by their guide. The reason for this orientation, according to the teachers, is the difficulty of the subject. If the teacher believes that the subject is so complex that the student cannot learn it on his/her own, the teacher will assign the student a passive role.

Since the students will have difficulty understanding this topic, the teacher explains it to them and the students fill out the diagram themselves (T-1).

It's better if I explain the concepts. Otherwise, it would be worse if they learn something incorrectly. That's why it makes more sense for me to explain the hard concept (T-2).

Examining the science teaching orientations of the science teachers in terms of their gender, it can be seen that there is a significant difference between male and female teachers in favor of female teachers $(\mathrm{t}=2.022$, $\mathrm{p}<0.05)$. This indicates that gender has an impact on science teaching orientations and that the orientations of female teachers are significantly more liable to exhibit guided inquiry orientations than those of male teachers. On the other hand, the orientations of both male and female teachers are on the level of guided inquiry. 
It was found that there were differences between the arithmetic means of the science teaching orientation scores of the Science teachers in terms of their professional seniority. Teachers with 11-20 years of professional experience had the highest arithmetic means. Thus, it may be said that the teachers who comprised the middle group of teachers were more liable to exhibit guided inquiry orientations as compared with the other groups of teachers. On the other hand, the orientations of both teachers at all professional seniority levels favored guided inquiry. The ANOVA was used to determine whether the difference observed between professional seniority levels was significant; the Tukey test was employed to understand from which groups the differences stemmed. It was ascertained that there was a significant difference in orientation between the teachers of 1-10 years and those of 11-20 years, with the difference being in favor of the latter group $(\mathrm{F}(2-92)=4.263, \mathrm{p}<.05)$. No other significant differences could be found.

Examining the science teaching orientations of the Science teachers in terms of their schools displayed a significant difference in favor of the teachers working in the city center. This is an indication that the location of the teacher's school may affect pedagogical orientation. Teachers working in the city center showed a pedagogical orientation that favored guided inquiry as compared to those working in the districts.

\section{Discussion and Conclusion}

According to the first conclusion of the study, the teachers' science teaching orientation is on the level of guided inquiry. In other words, the student tries to learn a previously determined concept of science by exploring the phenomenon or concept under the teacher's guidance. When the matter is examined from the standpoint of the change in the program introduced in the 2004-2005 academic year, it can be said that the science teaching orientations of the teachers are similar to the emphasis on investigation that the program recommends. However, although the understanding of student-centered teaching promoted in the program and the teachers' viewpoint of emphasizing investigation-based learning appears to be compatible, when analyzed from the perspective of a particular method of teaching, it can be said that this viewpoint may diverge from the understanding adopted in the program.

The matter of gender appears to emerge once again as a factor that impacts science education applications. It was determined in the study that a significant difference exists between the science teaching orientation of Science teachers of teachers with 1-10 and with 11-20 years of experience, and that this difference is in favor of the more senior teachers. In effect, while it might be expected that teachers that are relatively newer in the profession would have orientations that would be more likely to favor guided inquiry, the scores of the more senior teachers were higher. Under the circumstances, this suggests that new teachers are in conflict between the awareness of their knowledge and skills in teaching and their inability to directly use these in classroom applications. Since teachers are able to find solutions to resolve this conflict as they gain new experience, it may be that as their professional seniority increases, their pedagogical orientations may turn toward favoring guided inquiry. The study found that the location where teachers worked had an effect on their pedagogical orientations. In the light of these results, studies based on more process-focused research techniques may be conducted to examine the effect of the approach of other teachers and administrators, the physical conditions of a school, and the cognitive presence of students on pedagogical orientation. 